\title{
Egyptian Political Satire: Parsing the Rhetoric of Parody in Īhāb Ṭāhir's Mursī qalb al-asad
}

\author{
Dr. Ahmad M. Ali \\ Lecturer in Linguistics \& Translation, Helwan Univ., \\ Egypt \& Visiting Scholar, Emory Univ., USA \\ E-mail: ahmad_ali@arts.helwan.edu.eg; aali0078@gmail.com
}

\begin{abstract}
:
Political satire is employed by writers to voice their own opinions, using irony, sarcasm and allusions to criticize social, economic or political issues, or to indicate mockery of salient figures, especially politicians. In this respect, this paper will analyze a literary work by Īhāb Țāhir, entitled Mursī qalb al-asad 'Mursī, the lion's heart' (2013), issued two years after the $25^{\text {th }}$ January Revolution. Țāhir, through his satirical and political parody, attempts to find an emotional vent, for the ordinary people of Egypt, through which they could get rid, even if temporarily, of their recurrent encumbrances and burdens of life, enabling them to restore their stolen democracy, freedom of expression, and liberty by the rigid regime of Mursī, the former president of Egypt, and his party, the Muslim Brotherhood (MB). Depending greatly on Paul Simpson's (2003) theoretical model of satirical discourse analysis, this paper attempts to propose a Pentadic Satirical Script Theory of Verbal Humor (PSSTVH). By employing this proposed theory, Țāhir's style of writing, through which his satirical activity is delivered, and his satirical techniques, adopted to convey his message efficiently, will be investigated.
\end{abstract}

Key words: Political satire, parody, fantasy, democracy, January 25 Revolution, emotional vent, Pentadic Satirical Script Theory of Verbal Humor (PSSTVH). 


\section{السخرية السياسية في مصر :}

طرح تجليات المحاكاة الساخرة في امرسي قلب الأسده لإيهاب طاهر

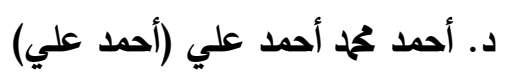

مدرس اللغويات والترجمة، قسم اللغة الإنجليزية، كلية الآداب، جامعة حلوان

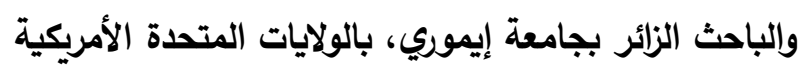

يتناول الكتًاب السخرية السياسية كوسيلة من وسائل التعبير عن آرائهم الخاصة

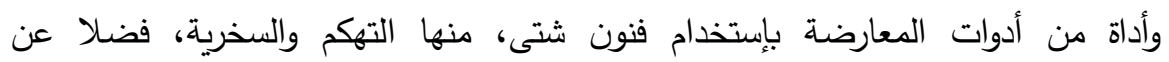

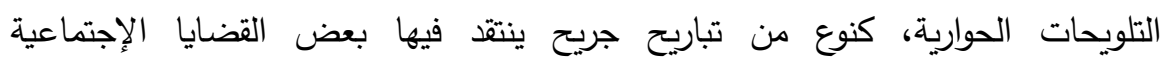

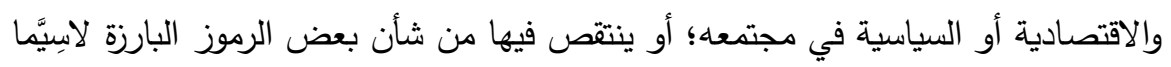

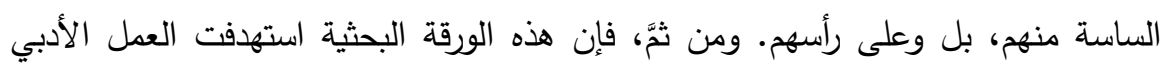

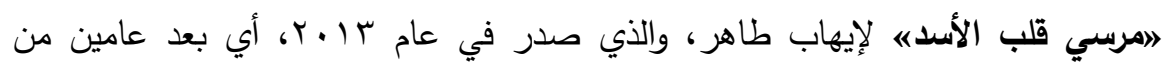

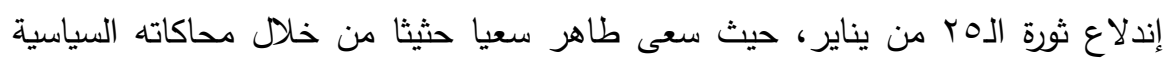

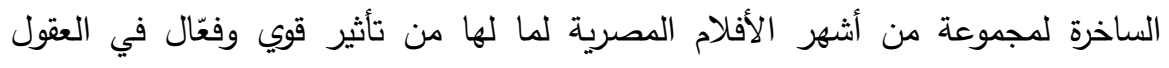

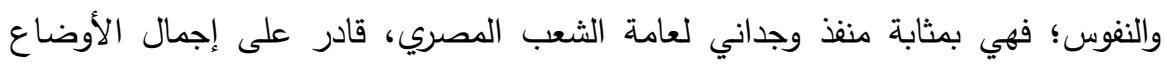

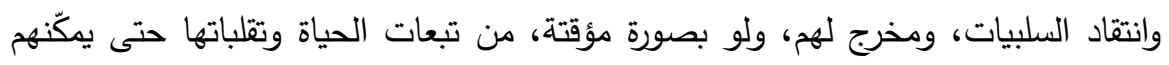

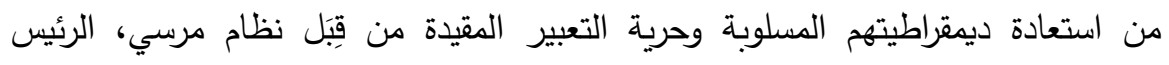

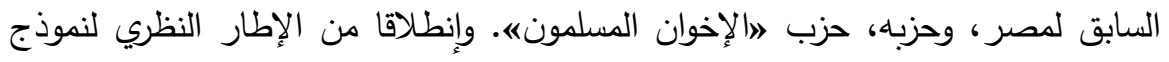

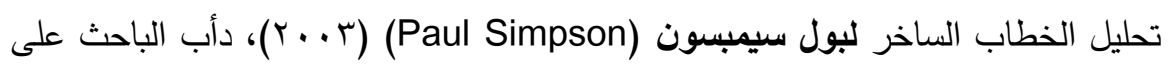

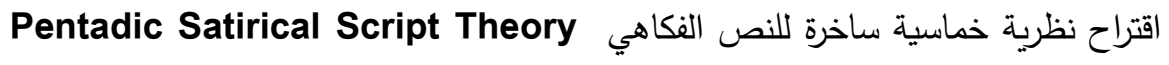
of Verbal Humor (PSSTVH)

$$
\text { الكتابة وأدوات السخرية في العمل محل الدراسة. }
$$

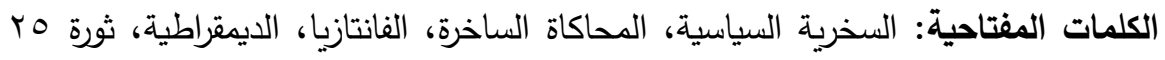

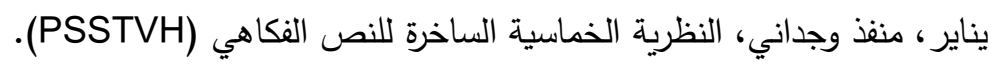


Egyptian Political Satire: Parsing the Rhetoric of Parody in Īhāb Ṭāhir's

Mursĩ qalb al-asad

Dr. Ahmad M. Ali

مجلة وادي التيل للاراسات والبحوث الإنسانية والاجتماعية والتريوية (مجلة علمية محكمة)

\section{Egyptian Political Satire: \\ Parsing the Rhetoric of Parody in Īhāb Ṭāhir's Mursī qalb al-asad}

\section{I- Introduction}

Īhāb Ṭāhir: a satirist \& a parodist

İhāb Țāhir ${ }^{1}$ is one of the most popular contemporary Egyptian satirists, whose most of his satirical works, except a few ${ }^{2}$, came into existence in the year of the Egyptian Revolution of 2011, known as the 25 January Revolution. His first work of satire was ra'šs ğumhūriyyit nafsī 'The President of the Republic of Myself', which was published in 2010 ( $4^{\text {th }}$ ed.). Tāhir's early shtick obviously appeared in political critiques as an appropriate means to 'influence social' and political 'change' (Rosen, 2012). He firmly believes that satire is an effective tool and 'a defensive mechanism', capable of relieving 'tensions' and reducing 'anxiety' (Hmielowski, Holbert \& Lee, 2011). He has a large list of satirical works, totaling 20 works of humorous titles, including but not limited to tuzz fikum 'I don't care' ( $3^{\text {rd }}$ ed., 2010); hamra 'Red' ( $4^{\text {th }}$ ed., 2010); dawlit baba 'My Dad's Nation' (2011); al-fankūšs 'nonsense' (2011); man antum 'Who are you?' (5 $5^{\text {th }}$ ed., 2012); hawāzīq 'stakes' (2012); ana ha-rakkib daqn wa-arūh li-abūkī 'I'll put on a beard, and go to your dad' (2012). All his satirical works focused primarily on attacking the regime and encouraging the Egyptians to resist oppression and injustice, to 'publicly express feelings' of revolt, and to 'challenge the course of action' (Ibrahim \& Eltantawy 2017). TTāhir, as his other Egyptian satirists, was coeval with Mubarak's regime (1981-2011), which lasted for 30 years. $\mathrm{He}$, as a satirist and as an Egyptian citizen, witnessed a period of 'dictatorship' and 'autocracy', represented in a president, who had an unlimited power, practicing despotism (Khamis, 2008; Cottle, 2011, as cited in Ibrahim \& Eltantawy, 2017). Tāhir is considered to be muhadram, as he has lived 'through two generations' or witnessed two historical 'epochs' (Alansari, 2009, p. 17), i.e., the era of Mubarak and that of Mursī, a member of the 
(ISSN : 2536 - 9555)

Muslim Brotherhood (MB). Accordingly, his satirical writings are a direct and immediate response to troubled times and social restrictions the Egyptians went through during the two regimes, representing 'the voice of his community' (Gray et al., 2009, p. 16).

\section{Țāhir's work in brief}

Țâhir divides his satirical work into two parts; the first part expressly and directly criticizes and comments on the abuses of Mursī's regime, counting his presidential blunders and his socalled achievements. In other words, Țāhir contemptuously criticizes Murs̄̄'s pseudo-achievements and humorously mimics the masterpieces of the Egyptian cinema, using a language that provokes the reader's laughter and directs him unintentionally towards the author's expectations, i.e. the stepping down of Mursī, as declared explicitly in his Dedication as in ila kull al-räfịīn lihukm al-ihwwān wa-Mahammad Mursī 'to those who refuse the regime of the MB and Mahammad Mursī' and the revival of Egypt, which is not 'izbit al-ihwwān aw nağ' al-Muršid aw kafr al-S̄ạtir 'the MB's manor, or al-Muršid's hamlet, or al-Šațir's village'.

In the second part, Tāhir, through his distinctive literary style, re-dramatizes sarcastically some of the most famous Egyptian cinematic pastiches, as will be shown and analyzed below. This part consists of 16 chapters, imitating satirically the Egyptian movies. Tāhir titles his chapters with fitting satirical sub-titles of the movies he imitates, followed by the real title of the movie accompanied by the word sābiqan 'formerly', as in film Mursī qalb al-asad "al-nāșir Șalāh al-Dīn" sābiqan; wā-mișrāh "wā-islāmāh" sābiqan; šay' min al-ğahl "šay' min al-hawf" sābiqan, etc. Other movies include only the real titles without any satirical reference to Mursī, especially the last three chapters, as in al-rağul al-tānn 'the second man'; al-gaybübah 'syncope'; and kidbit abrīl 'April Fools' Day'. Tâhir starts the second part with the chapter that carries the title of the book, i.e., Mursī qalb al-asad. All these chapters are commonly sharing a caricature of Mursī, which represents the fake 


\section{Egyptian Political Satire: Parsing the Rhetoric of Parody in Īhāb Țāhir's Mursĩ qalb al-asad}

Dr. Ahmad M. Ali

مجلة وادي النيل للاراسات والبحوث الإنسانية والاجتماعية والتريوية (مجلة علمية محكمة)

knight who rides a wooden horse. Additionally, each fantasy initially contains a list of the names of the heroes, who are different from those of the real movies. To explain, Tāanir includes various and real characters in his work from different backgrounds. For instance, Mahammad al-Barad' $\overline{1}$ represents the liberal trend; Hamdīn SSabbāḥī represents the leftist trend; Hazim Abū-Ismā'îl represents the Islamist trend; Maẓhar Šāhīn represents Al-Azhar; 'Amr Ḥamzāwī represents the moderate liberal trend, to name just a few. They are taken from reality but the scenario is fabricated and interwoven from Țāhir's own imagination. Țāhir seems here to be the authoritative voice and the omniscient author, who controls the events and chooses freely the characters participating therein. Egypt is a major character in most of the fantasy movies, implicitly or explicitly. It is explicitly mentioned in the movie of wā-missrāh "wä-islāmāh" sābiqan under the name of Mașr 'Egypt', but it is implicitly mentioned in the movie of rudd baladi "rudd qalbī" säbiqan under the name of Injī, the main heroine of the original. Mursi is also the common factor and the principal character in all of these movies. Another common feature all the chapters share is the reference to the scenarist of these fantasy movies, as in sinary $\bar{u}$ wa-hiwār wa-ihrāğ wä-muntāğ al-'abd-lillāh. Tāhir refers to the four processes of writing each fantasy movie, i.e., the scenario, dialogue, direction and montage. He indefinitely refers to the author of these fantasy movies anonymously; he uses a penname, i.e., al-'abd-lillahh, a religiously based epithet indicating one's selfdenial according to the Egyptian culture. Additionally, Tāhir professionally borrows dramatic phrases or dialogues from the original to give the reader a real atmosphere in which s/he flashes back the events, as shown later.

\section{The purpose behind Tāhir's work}

Țāhir, in his Prologue, announces the purpose behind his book; he rejects the idea of writing his book to document Mursì's regime or to have the events of the MB chronicled; he does not want to disturb the peace of his dear reader or to remind them of the 
endless pains. On the contrary, his optimal want is to draw a smile on his reader's face, especially during a period of hard times such as has not been experienced over the last 30 years of Mubarak's regime.

Țāhir writes a declaration in his Prologue to his readers about the criticism of Mursī. He admits that he does not criticize Mursī personally, as there is no hostility between them; he neither hates nor likes him. He enumerates his blunders and the wrongdoings he has committed as the president of Egypt. He believes that none is above criticism even the presidents of one's country. He is of the opinion that as long as Mursī is not a prophet, then he is liable to criticism. In other words, "if politicians were angels, no satire would be necessary" (Peterson, 2000, p. 207). Then, Ṭāhir quotes Ibn Hazm al-Andalusî's ${ }^{4}$ saying: man ištagala bi-al-umūmah 'alayhi an yatașaddaq bi-nisf 'irdih "those who submissively serve the public good be susceptible to personal cynicism". In doing so, he gives himself the right to criticize Mursī, who had the right to work as a public servant.

\section{Egyptian Political Satire}

"The Egyptians are particularly prone to satire", as Edward Lane (1908) remarks, they "display considerable wit in their jeers and jests" (p. 314). "Their language affords them great facilities for punning", targeting their autocratic rulers, lampooning "those enactments of the government by which they themselves most suffer" (p. 314). Political satire in Egypt witnessed a period of fluctuations through history. In the end of the $19^{\text {th }}$ century, Nabîl Rāgib (2000) states, through his chronicle of historical events and dynasties, the partial flourishment of the 'satirical press' on the hands of Ya' qūb Șannū' (1839-1912) and 'Abdallah al-Nadīm (1845-1898), whose salient contributions were obviously effective (p. 9). After the 1952 revolution, satire, as Rāgib (2000, p. 37) claims, "almost disappeared in Egypt", as it "no longer came from the thoughts and consciousness of the writer, but rather became state-directed $\ldots$ so it lost its brilliance, sharpness, and 


\section{Egyptian Political Satire: Parsing the Rhetoric of Parody in Īhāb Țāhir's Mursĩ qalb al-asad}

Dr. Ahmad M. Ali

مجلة وادي النيل للاراسات والبحوث الإنسانية والاجتماعية والتربوية (مجلة علمية محكمة)

cheerfulness"; "[t]he space of satire faded out from the pages of the newspapers and magazines", except for "only scattered fragments from" Mạ̣mūd al-Sa dan̄̄, Aḥmad Bahğat and Aḥmad Rağab "was left" (as cited in Håland, 2017, p. 144).

The pursuit of the historically satirical activities, including the press, newspapers, graphs, media, TV, radio, etc., demonstrates the richness of the movements of the national resistance primarily achieved and expressed by satirists. Although the Egyptian political satire had not been exclusively and freely practiced in the end of the $19^{\text {th }}$ century, due to the restraints and the oppression imposed by the political regimes upon the satirists, but they gradually expressed their views either 'directly' and 'confrontationally' or 'indirectly' and 'covertly' (Anagondahalli and Khamis, 2014, p. 12). To explain, as for the direct and explicit satirical works, the work under study, i.e., Mursì qalb al-asad (2013) by TTāhir, and didd al-ra 'T̄s 'against the president' (2006) by 'Abdel-Halīm Qandīl represent the open free expression. Like Țāhir's literary and satirical works that mock Mursī's regime and his grieve mistakes, targeting the Muslim Brotherhood party, all Qandīl's satirical works target directly the president Mubarak and his family, opposing the future potential presidency of his son, Ğamāl.

On the other hand, indirect and implicit writings of resistance were adopted, for example, by Ğalāl 'Āmir (1952-2012), the author of Massr 'ala kaff 'afrīt 'Lit. Egypt on a genie's palm' (2009) and the daily satirical columnist of tahārī 'hallucinations' in al-Massri al-Yawm newspaper; Mahmūd al-Sa 'danī (1928-2010), the author of Mudakkirāt al-walad al-šaqī 'memoirs of the naughty boy' (1990), Mașr min tān̄ 'Egypt once again', Amrīka yā-wīka 'America, $y \bar{a}$-wìka', musāfir 'ala al-rașif 'Traveler on the platform' and humār min al-šarq 'a donkey from the East'; Muștafa Amīn, the author of the symbolic novel $L \bar{a}$ 'no', which later became a TV series, tahya al-dimuqrātiyya 'Long live 
democracy', sana ūla siğn 'first year in jail', afkār mamnū 'ah 'forbidden ideas', etc., and the founder of Ahbār al-Yawm newspaper with his brother 'Alī Amīn; and Aḥmad Rağab (19282014), the author of many satirical writings such as yawmiyyatt himāar 'a donkey's diaries', șuwar maqlūba 'overturned pictures', Ayy kalām 'nonsense', nahārak sa 'ìd 'good day to you', etc., and the author of nușs kilma 'half a word', i.e., the daily satirical column in Ahbār al-Yawm.

The freedom of expression was not enough, owing to the iron fist of the state of fear, but it was at least a 'release of aggression' and an outlet or vent of anger by the oppressed. This category of writings is labelled Adab sāhir (satirical literature), employing the Egyptian 'ämmiyyah 'vernacular' or fușha 'the Standard Arabic', opposing the growing interest in other "genres of 'popular' literature" (Jacquemond, 2016, p. 356) "such as romance and horror" (Håland, 2017, p. 142). The Egyptian vernacular was, and still is, the most preferable medium, entirely or partly, through which satirists convey their message of objection to change the social and political life, represented in their autocratic rulers, especially through the press in the late $19^{\text {th }}$ and early $20^{\text {th }}$ century (Fahmy ${ }^{5}, 2011$, as cited in Ibrahim \& Eltantawy, 2017, p. 2808). They relied greatly on the colloquial Egyptian, rather than the formal Arabic, as a 'substantial freedom to mock' (El Amrani, 2011, as cited in Ibrahim \& Eltantawy, 2017, p. 2808).

The gradual liberation of the press and the media in the 1990s and early 2000s, during Mubarak's presidency that lasted for 30 years, was the urgent outcome of the media and the press privatization, the rapid spread of social media such as Facebook, Twitter and Instagram, and the satellite TV. These recent technological developments at the time contributed to the emergence of 'private opposition newspapers and satellite channels like al-Birnāmiğ by Bāsim Yūsif. He started his own episodes on the YouTube in the aftermath of the 25 January 2011 as a kind of personal resistance, till his show became famous, achieving 


\section{Egyptian Political Satire: Parsing the Rhetoric of Parody in Īhāb Țāhir's Mursĩ qalb al-asad}

Dr. Ahmad M. Ali

$$
\text { مجلة وادي الثيل للاراسات والبحوث الإنسانية والاجتماعية والتربوية (مجلة علمية محكمة) }
$$

unprecedented success. His optimal goal was to unveil the fake events and news transmitted by the state-owned media at the time. Later, Yūsif scathed openly Mursī's regime and his cabinet, opposing his political policy, directing his followers and viewers' awareness to his failure as the president of Egypt, leading, finally, side by side with other talk shows, to his abdication in 2013. Thus, the role of social media and the growing voices of resistance were of great impact resulting in the stepping down of Mubarak and Mursī, respectively (Ibrahim \& Eltantawy, 2017, pp. 2808-9).

\section{Review of the Literature ${ }^{6}$}

In his article entitled "Political Satire in Egypt during the Last Decade: A Linguistic Perspective" (2011), Hesham Hasan investigates the satirical book entitled didd al-ra'sis 'against the president' (2006) written by the Egyptian satirist 'Abdel-Halīm Qandīl, who publicly opposed Mubarak's regime and frankly objected to the scheme of Gramāl's succession to the throne of Egypt. Hasan focuses on some extracts taken from Qandīl's book, which includes his collected satirical articles he wrote during his position as an editor of chief for some opposition newspapers in Egypt, to be analyzed linguistically. Hasan praises Qandīl's courage to counter injustice and oppression of the regime at the time without adopting any psuedonyms; he considered him to be one among "the vanguards and forerunners of the Arab Spring" ( $p$. 11). Employing Simpson's (2003) SMUT model of satire, which consists of four components, i.e., 'setting', 'method', 'uptake', and 'target', Hasan linguistically analyzes Qandīl's satirical work. He discusses these four components thoroughly in the book of Qandīl, and then he investigates some aspects of 'linguistic innovations' inherent in Qandīl's satirical style, including 'phonological coinage', 'new word collocation', 'blending', 'new derivatives', 'poetic register', 'religious register', 'allusion', 'colloquialism', and 'irony' (pp. 22-3). 
(ISSN : 2536 - 9555)

Eva Marie Håland, in her chapter entitled "Adab Sākhir (Satirical Literature) and the Use of Egyptian Vernacular" (2017), traces the literature of satire in Egypt in the period 2011-2014. However, the people's growing interest targeted other 'different types of novels', primarily focusing on popular topics such as 'humor', 'romance', and 'horror'. Then, she explores the language in which the 'new wave' of satirical literature, through the analysis of around 21 books released between the 2011 and the 2014, was written. It is, as Håland puts it, a combination of fushha 'Standard Arabic' and 'ammiyyah 'the Egyptian vernacular', which was commonly and preferably used at the time. Thus, Håland investigates the stimulus behind the preference of writers in the period of 2011 and 2014 to use 'ammiyyah, focusing primarily on 'the narratives mode', 'the humorous elements' included, 'the classification' of the chosen works as satirical writings, 'the codeswitching' between the 'two language varieties', 'the coinage' of the new term Fushämmiyya by Rosenbaum (2000, p. 71), 'the lexical choices' and their 'etymology', and the situation-based diglossia. In her conclusion, she emphasizes that al-Adab al-Sāhir is not a 'new' genre, but it is a 'popular' and common one, which depends on 'humor' as a means of 'entertainment' to fulfil 'correctional goals' through directive 'criticism'. She concludes her chapter with the remark that use of 'ammiyyah is favorable in the Egyptian culture, and it is an acceptable means of receiving the writers' correctional goals.

In their article entitled "Egypt's Jon Stewart: Humorous Political Satire and Serious Culture Jamming" (2017), Ibrahim and Eltantawy analyze the famous Egyptian TV satire show alBirnāmiğ presented by the Egyptian satirist Bāsim Yūsif. They introduce Yūsif to the audience, tracing his previous profession as a heart surgeon, which he abandoned and practiced the profession of media, focusing on the political circumstances that paved the way for him to be one of the salient satirists in Egypt, nicknamed "Egypt's Jon Stewart". Following the same model of the American TV satirist John Stewart, his reputation and satirical style became 


\section{Egyptian Political Satire: Parsing the Rhetoric of Parody in Īhāb Țāhir's Mursĩ qalb al-asad}

Dr. Ahmad M. Ali

$$
\text { مجلة وادي التيل لللاراسات والبحوث الإنسانية والاجتماعية والتربوية (مجلة علمية محكمة) }
$$

commonly popular not only in Egypt, but also in the Arab world. They discuss the earlier of Yūsif, which were the direct outcome of the fallacies and lies transmitted by the state-owned media during the communal resistance in the Revolution of 2011. They demonstrate that Yūsif's satirical motivations emerged from the political events, starting from the uprising of January 2011, continuing through the post-revolution presidential elections of 2012 between Muhammad Mursī, a member of the Muslim Brotherhood, and Šafĩq, a representative of Mubarak's old regime, the presidency of Mursī and his overthrow until the interim presidency of 'Adlī Manșūr. Their article focuses on Yūsif's main target of satire, that is, Mursî̀'s regime. It discusses Yūsif's satire mocking Mursī's intervention in the constitution that outraged the Egyptians, the Pakistani hat he wore at the honorary doctorate in Pakistan, a ridicule that caused a diplomatic crisis between the two countries, and Mursī's international etiquettes, including his 'broken' English accent and his fiddling with his watch during a press conference with Angela Merkel, the Chancellor of Germany. They also investigate Yūsif's satirical techniques such as his use of the character of Gamāhìr 'the masses' represented by the audience, his use of defensive and 'bold' language, which increased his fans and followers all over the Arab world, and his ridiculous juxtaposition of comic clips, for the purpose of humor and play, so as to "expose hypocrisies in media coverage, illuminate inconsistencies, and facetiously reveal folly" (Anderson \& Kincaid, 2013, p. 171).

Adi Maslo (2019), in his article entitled "Parsing Satirical Humor: A Model of Cognitive-Linguistic Satire Analysis", explores the satirical aspects of the fake news TV program, The Daily Show, aired on Comedy Central. In this article, Maslo attempts to propose 'an integrated cognitive-linguistic' approach to verbal and visual satire, benefitting greatly from the Blending Theory or Conceptual Integration Theory by Fauconnier and Turner (2002) and the General Theory of Verbal Humor by Attardo 
\& Raskin (1991) with its six Knowledge Resources (KRs), i.e., Script Opposition (SO), Logical Mechanism (LM), Situation (SI), Target (TA), Narrative Strategy (NS), and Language (LA). The findings of his proposed approach are limited to the elicitation of the three main features of the satirical show. In his explanation of the definition of satire, Maslo discusses the concept of 'incongruity', that is, the "conflict between what is expected and what actually occurs" (Shultz, 1976, as cited in Ritchie, 2004, p. 48 ) in the satirical discourse, in both 'humorous' and 'nonhumorous' discourses. His analysis, which includes 155 episodes of The Daily Show's fake news, introduces a slight modification to the order of the six (KRs), in which priority is given to the highest in the hierarchy. To clarify, Maslo re-arranges the six KRs in terms of the priority of the satirical discourse, which differs from Attardo \& Raskin's, as follows: SO, LM, TA, LA, NS, and SI instead of SO, LM, SI, TA, NS, and LA. Maslo's other contribution is the slight modification of the two conceptual opposing input spaces; he proposes the term 'thesis', referring to 'true input space', and 'antithesis', referring to 'fake input space'. He believes that 'true' and 'fake' are compatible terms with the satirical script of the fake news program; these two proposed terms are called 'prime' and 'dialect' by Simpson (2003, pp. 8-9).

In "Post-coup recuperation in al-Manawahly's songs" (2020), Noha Radwan attempts to analyze some of the songs of the Egyptian musician and songwriter, Yāsir al-Manawahlī, who is regarded as one of many 'voices of the new revolution', i.e., January 2011 Revolution. His songs are very expressive of the revolution's demands, which are 'bread', 'freedom', and 'social equity'. Radwan targets his two famous songs, i.e., ahì riğ it rìmah 'Rīmah is back' and țili 't quffah 'I turned out to be a fool', which were released in 2014 and 2016, respectively. His video hăayf 'Afraid' was released shortly after the previous two songs. Radwan examines the reasons behind the noticeable change in the 'butts' of the political satire. In the songs, she attempts to find the actual impetuses that pushed al-Manawahlī to divert his satirical route 


\section{Egyptian Political Satire: Parsing the Rhetoric of Parody in Īhāb Țāhir's Mursĩ qalb al-asad}

Dr. Ahmad M. Ali

مجلة وادي النيل للاراسات والبحوث الإنسانية والاجتماعية والتربوية (مجلة علمية محكمة)

from criticizing the political regime and policies of Egypt, as he was an opponent to Mursî̀s presidency (2012-2013), to adopting a new satirical critique of him. Thus, the core of her article answers her question, regarding the efficiency of songs in shifting the route of the Egyptian revolution.

\section{Scope of this paper}

This paper attempts to investigate and analyze the most outstanding aspects of, not all, satirical techniques, in which the work of Īhāb Țāhir is rich. Before investigating comprehensively the role of satire in Taanhir's work, it is necessary to begin with an investigation of satire itself.

\section{Al-adab al-sāhir 'satirical literature' (Håland 2017)}

Ràgib (2000) precisely and concisely defines the concept of suhriyyah 'satire' in literature, which targets either a 'time', or a 'place', or 'people', with some certain goals, as stated below:

[Suhriyyah] in literature is the element that contains a dramatic mixture of criticism $^{7}$, derision, allusion, insinuation, mockery and funmaking, for the purpose of exposing a person, concept, idea or whatever, and laying it bare by throwing light on its cracks and its negative and deficit aspects. Thus, the primary goal of [adab sāhir] is correctional, either on the moral (or aesthetic level, and it differs in tone and manner from all other ways of expression that aim to reject, condemn or belittle the subject targeted by the writer or speaker. (p. 3, as cited in Håland, 2017, p. 113)

In this regard, Lūwīs 'Awaḍ (1915-1990), an Egyptian thinker, a critic, and a writer, elaborates, in his foreword to Aḥmad Bahğat's (2009) mudakkirāt zawğ 'memoirs of a husband', on the definition of al-adab al-sāhir. He argues that it is the 'legitimate son' of adab al-hiğ $\bar{a}$ ', and the 'cousin' of al-adab al-fukāhi 'humorous literature' (Bahğat, 2009, p. 6, as cited in Håland, 2017, p. 144). 
(ISSN : 2536 - 9555)

"The combination of biting vernacular humor and satire", as Ziad Fahmy (2011) believes, "greatly enhanced the popularity and political effectiveness" of satirical critiques. "Their novelty, entertainment value, and accessibility to the masses", Fahmy adds, "greatly contributed to the delegitamization of the ruling regime and helped to focus Egyptian anger on" corruption, injustice, and inequity (pp. 51-2).

\section{Parody as Satire (Gray et al. 2009)}

Parody comes under the umbrella of satire; it is one form of satire, which is the most common form of humor. It may include 'any form of artistic expression', like 'a poem, a story, a religious text', a 'non-fictional' piece of art, a movie, etc. Thus, it has to be parallel with the original, raising the awareness of the audience or the readers towards matching the 'distortions' and 'incongruities' inherent in the given work (cf. Gray et al., 2009, pp. 17-19). Parody, as Gray et al. (2009) said, is "an important contributor to political discourse, encouraging critical viewing and a healthy cynicism about the mediation of politics" (p. 18). On the part of the audience, parody brings about "reflection and re-evaluation of how the targeted texts or genre works" (Laurent, 1982, p. 59; emphasis in the original), as it produces 'new' ways of interpretation of the 'old texts or genres' (Gray et al., 2009, p. 18).

Satire derives from the Latin term satura, meaning "a mixed dish" (Holbert, Tchernev, Walther, Esralew, \& Benski, 2013; LeBoeuf, 2007, p. 2). According to Test (1991), it is "a legitimate aesthetic expression of basic human emotions- anger, shame, indignation, disgust, contempt- emotions that are aroused by universal human behaviors- stupidity, agreed, injustice, selfishness" (p. 5), which "satisfy people's need for humor" (Ibrahim \& Eltantawy, 2017, p. 2806) and amusement. It focuses on some certain aims to be taken into consideration, including 'sarcasm', 'ridicule', 'criticism', and 'hypocrisy'. It attempts to prove that appearances can be 'deceptive' and misleading. Distortions and exaggerations are included among its aims, which 
Egyptian Political Satire: Parsing the Rhetoric of Parody in Īhāb Ṭāhir's Mursī qalb al-asad

Dr. Ahmad M. Ali

$$
\text { مجلة وادي التيل للاراسات والبحوث الإنسانية والاجتماعية والتربوية (مجلة علمية محكمة) }
$$

target 'often governments', or 'politicians', or 'the military', or 'the church', or 'the upper classes', or 'the conventions of the social life' (cf. Maslo, 2019, p. 232). Satire, as a 'process of transformation', requires two main participants: the 'author', who 'transforms reality' through the production of the satirical activity, and the recipient, who receives the author's satirical production and interprets it in terms of the real circumstances.

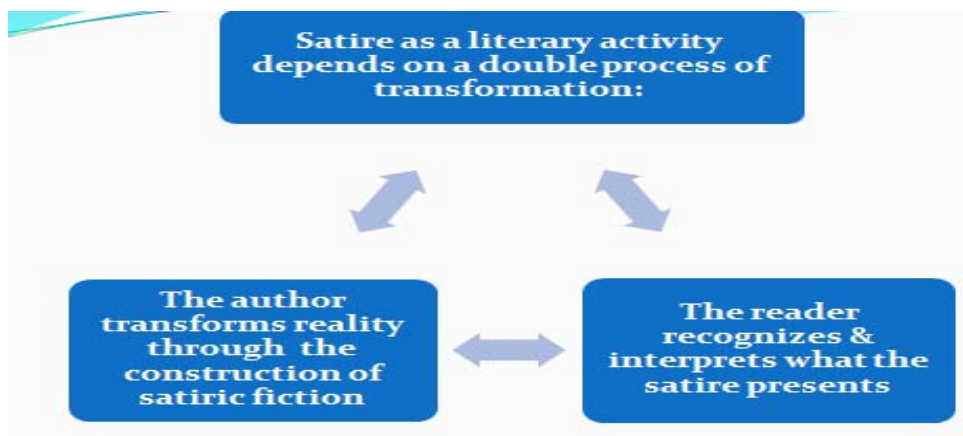

Fig 1. Satire as a process of double transformation

\section{II- Methodology}

Towards a Pentadic Satirical Script Theory of Verbal Humor (PSSTVH)

Depending greatly on Paul Simpson's (2003) theoretical model of satirical discourse analysis, this study attempts to propose a Pentadic Satirical Script Theory of Verbal Humor (PSSTVH). This model is considered appropriate for investigating satirical contexts, as it sheds light on the constituents or the components a satirical discourse consists of. According to Simpson, these principal constituents are three: 'the satirist', representing 'the producer' and the originator of the satirical text; 'the satiree', representing the 'addressee', whether a reader, a viewer or a listener; and 'the satirized', representing the oriented 'target', i.e., the object of satire (p. 8). The first two constituents, i.e., 'the satirist' and 'the satiree', are, as Simpson (2003) puts it, considered 'ratified' within the 
(ISSN : 2536 - 9555)

discourse of satire, whereas the third one, i.e., 'the satirized', is regarded as 'ex-colluded'. He calls this 'ex-colluded' target an 'invited participant', who may be an individual, a group of people, a government, a political regime, "an episode involving human agents, an aspect of more fixed or stable experience or existence, or even, crucially, another discursive practice" (as cited in Hasan, 2011, p. 12).

The satirical script theory proposed here is based on Simpson's (2003) theoretical model of satirical discourse, namely Simpson's three constituents, 'the satirist', 'the satiree', and 'the satirized', plus two other proposed primary constituents, which are the 'medium', i.e., the language, whether formal or informal, written or oral, through which the satirical activity is delivered, and, finally, the 'tools', which represent the satirical techniques employed by the 'satirist' to convey his message successfully and efficiently. Thus, the theory proposed here suggests that five constituents, namely 'the satirist', 'the satiree', 'the satirized', 'the medium', and, finally, 'the tools', form the basis on which any satirical script or activity depends. These five constituents will be expounded below in detail.

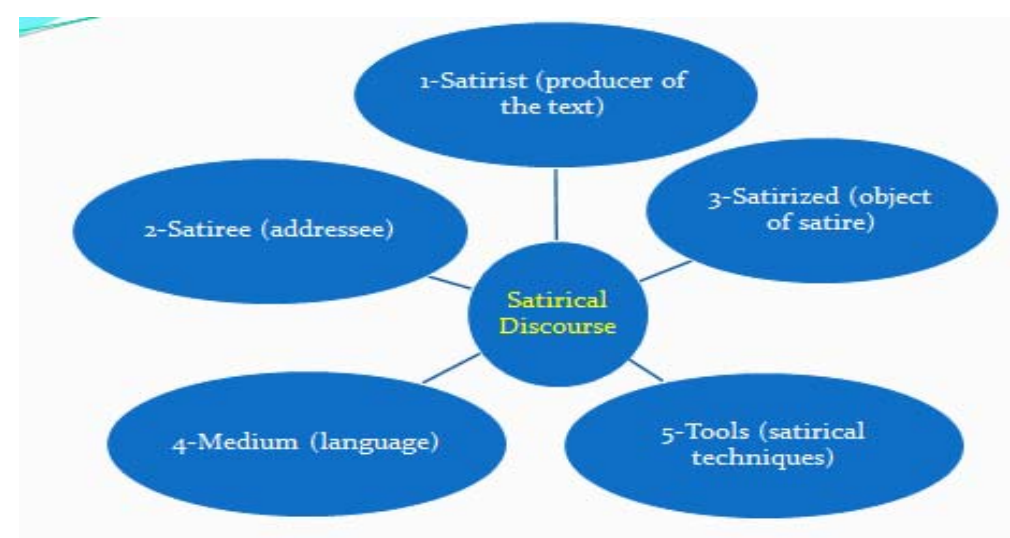

Fig 2. Pentadic structure of a satirical discourse 
Egyptian Political Satire: Parsing the Rhetoric of Parody in Īhāb Ṭāhir's Mursĩ qalb al-asad

Dr. Ahmad M. Ali

مجلة وادي النيل للاراسات والبحوث الإنسانية والاجتماعية والتربوية (مجلة علمية محكمة)

\section{The womb from which the PSSTVH emerged}

The proposed Pentadic Satirical Script Theory of Verbal Humor (PSSTVH) draws on other theories of humor, namely the General Theory of Verbal Humor (GTVH) proposed by Attardo \& Raskin (1991), Paul Simpson's (2003) model of satirical discourse, acronymed as "SMUT", Incongruity Theory (Beattie, 1776, p. 348; Kant, 1790, p. 177; Schopenhauer 1819, as cited in Attardo 1997, pp. 396-7), and Blending Theory outlined by Fauconnier and Turner (2002).

To explain, the General Theory of Verbal Humor (GTVH) is "an extension and revision of Raskin's script theory of humor and of Attardo's five-level joke representation model" (Attardo \& Raskin, 1991: 293). It focuses on the six Knowledge Resources (KRs), which are, as follows: Script Opposition (SO), Logical Mechanism (LM), Situation (SI), Target (TA), Narrative Strategy (NS), and Language (LA). This theory was later 'expanded' and 'redefined' by Paul Simpson (2003), as shown below.

In terms of compatibility with the GTVH (Attardo \& Raskin, 1991) and the Incongruity Theory (Beattie, 1776, p. 348; Kant, 1790, p. 177; Schopenhauer, 1819, as cited in Attardo, 1997, pp. 396-7), Simpson (2003), in his book entitled On the Discourse of Satire: Towards a Stylistic Model of Satirical Humor, proposes a theoretical model of satirical humor, labelled "SMUT", which stands for 'Setting', 'Method', 'Uptake' and 'Target'. His model is regarded as a re-modification of the 'main tenets of SSTH-GTVH' and the Incongruity Theory. He attempts to 'extend' and 'redefine' other aspects of the GTVH, specifically the concepts of 'setup' and 'resolution'. In his model of satire, Simpson investigates the "varying degrees of similarity or difference between some certain types of knowledge resources" such as 'language' and 'script opposition' (p. 44). 
(ISSN : 2536 - 9555)

Simpson's model is motivated by the contributions of his precedent theorists. 'Setting', the first component of his SMUT model, has been aspired from Nash's (1985) view on the prerequisites of any 'act of humor' requiring a genus, which implies "a derivation in culture, institutions, attitudes, beliefs" (pp. 9-10; emphasis in the original). He argues that the "GTVH also postulates the existence of a setup phase which precedes the incongruity phase chronologically" in Attardo's model (emphasis in the original). The "Setup" phase, as he clarifies, corresponds broadly to the notion of "script overlap" expounded in the SSTH by Attardo \& Raskin (1991) and the three-stage model of humor by Attardo (1997). Therefore, 'Setting', on his part, is "essentially a non-linguistic component", which encompasses "the preparatory preconditions necessary for the construction of satirical discourse" (Simpson, 2003, p. 70).

Being influenced by the 'principles of the GTVH', Simpson has borrowed only two phases out of the 'three-stage model of humor' (Attardo, 1997, p. 396) as stated in the second component of the SMUT model, i.e., 'Method'. These two phases are 'Setup' and 'Incongruity' (or script opposition), excluding 'Resolution', the third stage of Attardo's (1997) model. Attardo's (1997) model itself is an extension of the "two-stage" models of Suls (1972, p. 82), namely incongruity-resolution (IR).

Additionally, Simpson's (2003) third component of the SMUT model, 'Uptake', has been borrowed from Austin's (1962) concept of 'uptake', which relies on the comprehensibility of the 'illocutionary force' of the utterances and the 'perlocutionary effects' on the 'addressee' through the 'means of uttering the sentence' governed by the 'circumstances of the utterance' (1962, p. 116, as quoted in Simpson, 2003, p. 70).

Simpson's second reliance on the 'tenets of the GTVH' is clearly obvious in the proposed 'Target' in his SMUT model, which coincidentally or intentionally corresponds to the fourth Knowledge Resource, with some elaboration. To explain, he 


\section{Egyptian Political Satire: Parsing the Rhetoric of Parody in Īhāb Ṭāhir's Mursī qalb al-asad}

Dr. Ahmad M. Ali

مجلة وادي النيل للاراسات والبحوث الإنسانية والاجتماعية والتربوية (مجلة علمية محكمة)

describes the 'satirical target' and classifies it into 'four subtypes', as follows: episodic target (a particular action/ specific event), personal target (a particular individual), experiential target (human conditions and experiences), and textual target (the principal object of attack) (p. 71; emphasis in the original).

He simplifies the 'concept of incongruity', in his model, as a "largely semantic in its conceptualisation", and clarifies the "notion of script opposition', comprising two scripts, i.e., "the first is highly accessible and based on a neutral context, whereas the second opposed script is much less accessible and is strongly context dependent" (p. 38; emphasis in the original,). Simpson (2003), himself, admits that his model of satire is "over-reliant on the tenets of the GTVH", as the 'incongruity element' is "presented in terms of the concept of "script opposition", voicing "his specific reservations about both the narrowness of the script opposition approach and the problems attendant on the exclusion of a discourse-based approach" (p. 71). In other words, he (2003) expounds the 'incongruity phase' attendant on 'the broader notion of script opposition', 'through a number of overlapping discourse strategies', including "the creation of grotesques or caricatures ... [of] the object of attack; the merging ... of scripts and schemata; the transition between positive and negative polarities ... normal and abnormal scripts ... [and] ... possible and impossible discourse worlds" (p. 70).

As shown in detail above, these theories have common grounds; they are complementary in one way or another, as interconnectedness is clearly delimited. Thus, the new proposed theory under study is a (re)emergence of the previous theories. It is a new collection of the original, the modified, the re-modified and the proposed theories. It is an attempt to analyze the satirical work in hand through a proposed alternative perspective, as will be shown below. 
(ISSN : 2536 - 9555)

\section{III- Analysis}

Țāhir's satirical work is to be analyzed in terms of the five constituents of the proposed theory, 1- the satirist (the producer of the text); 2- the satiree (the addressee/the audience); 3- the satirized (the target); 4- medium (language), and 5- tools (satiric techniques).

\section{1- The go-to satirist}

Țāhir, as the producer of the text under study, attempts to criticize, satirize, and ridicule the prominent figure of the Muslim Brotherhood, 'the satirized' and 'the laughed-at target', using a 'humorous or deliberately exaggerated imitation' of serious master pieces of the Egyptian drama, mostly of cinematic works. His character as a political satirist is clearly depicted to be that of a "bluff-hater, cheat-hater, liar-hater, vanity-hater, but also that of a truth-lover, beauty-lover, simplicity-lover" (Elliot, 1960, p. 273). The intention of humor behind his satire is clearly stated in his Prologue, as follows:

Fa-ana lā urīdu an u'akkir șafwak ayyuha al-qāri' al- 'azīz 'ala qalbì aw aqallib 'alīk al-mawāği' bal urìdu an arsim basmah 'ala wağhik fì fatrah min as 'ab al-fatarāt allatī namurr bihā wā-ahlak al-zurūf

So, I do not want to disturb your tranquility, my dear reader, or to remind you of troubled times, but I want to put a smile to your face, specially, through the most hard times we go through. (p. 16)

So, his optimal goal is to relieve people's emotional suffering and intellectual disorders at the time of hardships and mistress, putting a smile on his readers' faces. In other words, his satire intends to "be funny in a belly laugh kind of way" (Gray et al., 2009, p. 4). He considers himself an "effective mouthpiece of the people's displeasure with those in power" (p. 4), including Mursĩ and the MB. 


\section{Egyptian Political Satire: Parsing the Rhetoric of Parody in Īhāb Ṭāhir's Mursī qalb al-asad}

Dr. Ahmad M. Ali

مجلة وادي النيل للاراسات والبحوث الإنسانية والاجتماعية والتربوية (مجلة علمية محكمة)

\section{1 Ṭāhir's concept of satire}

Ṭāhir in his Prologue quotes 'Amr Hạzāāī's saying on satire, who is an Egyptian academic and a political activist. Hamzāwī says:

Inna al-suhriyyah ğuz' min al-hayāh al-siyāsiyyah wa-haq min huqūq al-ra'y al-'ām lābudda min ihtrāmiha wā-'ilāğ al-nawāqiș lā yakūn bil-qam 'bal bil-hurriyyah. (p. 19)

Țāhir adopts the view of Hamzāwī, believing that "satire is part of the political life; it is considered one of the rights of public opinion that are to be respected [by all], and all the shortcomings and the [societal] blunders cannot be corrected by oppression but by freedom" (my translation, p. 19). This gives Țāhir the right to adopt a "subjective view of any aspect of social life", attempting to "contextualize satire as a social phenomenon" (Maslo, 2019, p. 232). Accordingly, this justifies Țāhir's approach to a "verbal aggression in which some aspect of historical reality", which "involves at least implied norms against which a target can be exposed as ridiculous", is "exposed to ridicule" (Fletcher, 1987, p. ix).

\section{2 Țāhir's satirical objectives}

Țāhir, through his satirical and political parody, attempts to find an emotional vent for the ordinary people of Egypt through which they could get rid, even if temporarily, of their recurrent encumbrances and burdens of life, enabling them to restore their stolen democracy, freedom of expression, and liberty by the rigid regime of Mursī and his party. Țāhir, as a political satirist, directs his attack to a specific individual, namely Muhammad Mursī, the former president of Egypt, and his political blunders, affecting the general order of the Egyptian society according to him. He, first, sets himself the task of awakening his audience to be aware of the gap between what really is and what could be and "to see realities that have been obscured" (Gray et al., 2009, pp. 16-17). Secondly, 
(ISSN : 2536 - 9555)

he aims at arousing his audience's laughter at the 'comic absurdity' inherent in the two parts of Țāhir's work, i.e., the fake achievements of Mursī and the Egyptian fantasy movies. In doing so, Țāhir directs his audience towards adopting an 'appropriate negative response', i.e., fa-laysa 'alayya wa- 'ala ša 'b Mașr siwa al-intizāar wa-law țăl 'I or the people of Egypt have nothing but to wait, regardless of time' (p. 11), for the hope of taking, in the future, a 'positive action', i.e., inna Mașr laysat kullahā ihwanniyyah 'surely, Egypt as a whole is not (the property of) the MB' (p. 19).

\subsection{Authorial intentions (Pfaff \& Gibbs 1997)}

Țāhir's Dedication is publically and openly divulged, as in: ila kull al-rāfị̣̂̄n li-hukm al-ihwwān wa-Mahammad Mursī ahdī kitābī hāda Mursi qalb al-asad. He lets the reader from the very beginning know that his recipients are those who stand against the Muslim Brotherhood's regime and those who reject the ruling of Mursī. He directly addresses his audience or readers, who have the right to receive his work. The Dedication expresses the satirist's personal perspective that is announced earlier on the cover page, including Abū-Ismā '̄il's disciples.

Țāhir dedicates his Foreword to the person whom he satirizes or criticizes, hoping to be mistaken in his perspective insights. Though the negative particle $l \bar{a}$ is unintentionally forgotten or missed, the intended meaning or the direct message is understood through the following context. To clarify, he says:

Atamanna an akūn qad tağannayt fì hukmī 'alīk ("Indeed, I hope I did you an injustice by judging (your behavior)") instead of atamanna alla akūn ("I hope I did not do"). (p. 11)

This previous statement semantically contradicts the following one,

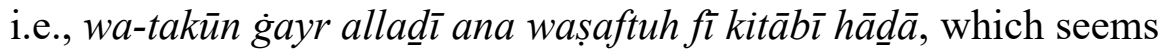
inconsistent with the misprinted phrase an akün, let alone other 


\section{Egyptian Political Satire: Parsing the Rhetoric of Parody in Īhāb Ṭāhir's Mursī qalb al-asad}

Dr. Ahmad M. Ali

مجلة وادي النيل للاراسات والبحوث الإنسانية والاجتماعية والتربوية (مجلة علمية محكمة)

mistakes in writing, such as hadțī instead of hadsī 'my intuition'. Finally, he asks his audience and the Egyptian people to do nothing but to be patient, no matter how long it takes.

\section{4 Ṭāhir's dilemma}

Țāhir declares from the very beginning his hostile and rejective attitude towards the Muslim Brotherhood's regime during the presidential elections between Mursī and Šafīq, justifying his refusal, as follows:

Rafaḍtu al-nuzūl la'nnī lam akun ara fì ayy minhuma aw fì simāt ahadihimā ma yaṣluh an yağ alahu ra '̄̄san li-Mașr ... ihtiyār ahadihima sawfa yuš irnī an lā šay' qad tagayyara 'ala ard Maṣr wa-anna al-tawrah ka-'annaha lam takun wa-anna šuhadā' 25 yanāyr qaddamū arwāḥahum habā'an wa-suddan

I refused to participate in (the presidential elections), as they both, in my view, lack the prerequisites of the presidency of Egypt ... choosing one of them will indicate that nothing has changed in the land of Egypt. (p. 13)

Having justified his refusal to participate in the presidential elections, Tāhir elaborates on his attack on the MB. He briefly criticizes Ahmad Šafĩq whom he considers a replica of Husnī Mubārak, the old regime. As for Mursī and his party, he recounts their past of suffering, torture, imprisonment, and oppression, not because they were innocent but due to their radicalism and intellectual extremism. Then, he epitomizes his dilemma through posing a set of rhetorical questions followed by immediate and direct answers, positive or negative. For example, he talks about the dream of that party to rule Egypt, but why? Is it for the benefit of Egypt or themselves? Do they consider themselves the best for this country? Or do they want to only seize power as they seek sovereignty 'in all of its meanings'? (p. 13). 
(ISSN : 2536 - 9555)

By raising a set of rhetorical questions, he gives the reader no option to reply or to think out of the box; the answers are of course directive; they direct the reader to opt for one negative answer. He, for instance, comments on his questions, saying: la aktar min hād $\bar{a}$ bigaḍ al-nazar 'an mașlahit Mașr 'no more than this, regardless of Egypt's benefit' (p. 13). For sure, he assumes no other possibilities; they are either the best leaders for Egypt, or they spare no effort to rule or control it. Degrading the character of Mursī, as a presidential candidate, accusing him of inexperience in politics and ignorance of his country's affairs, he questions his intentions, thoughts, and future proposals for Egypt in case of winning the elections. For all these justifications and reasonable opinions, according to him, Țāhir preferred to stay at home, refraining from participation in the elections, waiting for the undesirable expected result, that is, Mursī's victory over Šafĩ in the 2012 presidential elections.

\subsection{Subjectivity of the satirist}

Subjectivity of the satirist is "a distinguishing characteristic of the satirical tradition" (Klinkowitz, 1990, p. 82). TTāhir seems to be purely subjective, using his own personal pronouns and selfreferents, as in: fì hâd $\bar{a}$ al-kitāb a țaytu nafsì misāhah 'I gave myself in this book a space'; kull mā ata 'aqqaluhu wa-ahussuh 'all that I think and feel'; sa-aktafi 'will be enough for me to', to justify his understatement and degradation of the persona he attacks. He has one-sided view of life as he considers himself the voice and vicegerent of his society. To explain, he defines his goal of satire, that is, to protest against the MB and Mursī. In his Prologue, he reminds the readers of his refusal, inciting the Egyptian people to vote neither for Mursī nor for Šafìq during the 2012 presidential

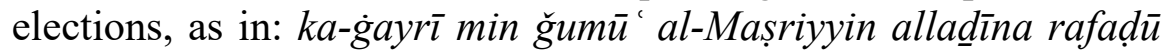
al-nuzūl ila al-intihāāāt al-ri'āsiyyah ... bayna Ahmad Šafíq and Mahammad Mursī 'as one of the majority of the Egyptians who refused to take part in the presidential elections ... between Ahmad Šafĩq and Mahammad Mursī’ (p. 13). He justifies his attitudinal and actual behavior on a fact that he believes firmly: Rafaḍtu al- 


\section{Egyptian Political Satire: Parsing the Rhetoric of Parody in Īhāb Țāhir's Mursĩ qalb al-asad}

Dr. Ahmad M. Ali

$$
\text { مجلة وادي النيل للاراسات والبحوث الإنسانية والاجتماعية والتربوية (مجلة علمية محكمة) }
$$

nuzūl la'nn̄̄ lam akun ara fì ayy minhuma aw fì simāt ahadihimā ma yașluh an yağ 'alahu ra'ìsan li-Maṣr. According to him, none of the two candidates has the appropriate requirements for being the president of Egypt. He is obstinately attached to a belief in disloyalty to Mursī and his supporters. Taāhir concludes his Prologue by giving himself a small space of freedom to express his own views and the views of the Egyptians neutrally and simply. He expresses his own views on behalf of the Egyptians; he does not exclude anybody, as follows: wa-'abbart min hiläliha 'an ârā' $\bar{l}$ wa-āra $\bar{a}$ al-Mașriyyin 'and through which I expressed my own views and those of the Egyptians' (p. 19). He represents the "Egyptians" even though his views are his own.

\section{2- The satiree (the addressee/audience)}

The addressees in Țāhir's satirical work are the Egyptian citizens, who are suffering from the same dilemma, i.e., the curse of Mursì's regime and the blunders of the Muslim Brotherhood. Taanhir dedicates the first few pages of his work to a plea to his readers to "analyze and interrogate power and the realm of politics rather than remain simple subjects of it" (Gray et al., 2009, pp. 16-17). For instance, Tāahir explicitly addresses his readers, i.e., ša 'b Mașr 'the people of Egypt', asking them gently to be patient, waiting and seeing the outcomes of Mursī's future as the president of Egypt, regardless of its duration fa-laysa 'alayya wa- 'ala ša 'b Mașr siwa al-intizār wa-law țăl 'I or the people of Egypt do not have but to wait, no matter how long it takes' (p. 11). Additionally, he mentions the addressees of his satire directly, expressing not only his own views of freedom he has, but also the views of alMașriyyin exclusively without exception, talking on their behalf, as

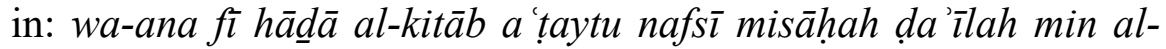
hurriyyah ... 'abbartu min hilāliha 'an ārā' $\bar{l}$ wa-ārā' al-Mașriyyin 'and I, in this book, gave myself a miniscule space of freedom ... through which I expressed my own views and those of the Egyptians' (p. 19). 
In another situation, Țāhir initiates his Prologue by reminding ğumū al-Mașriyyin of his refusal, together with all the massive majority of the Egyptian people, to vote either for Mursī or for Šafĩq during the 2012 presidential elections, as in: ka-gayrī min ğumū' al-Mașriyyin alladīina rafaḍu al-nuzūl ila al-intihāāāt alri'āsiyyah (p. 13). Thus, Țāhir is always eager, especially from the very beginning of his work, to emphasize that his readers are ğumu' al-Mașriyyin (the massive majority of the Egyptians), alMașriyyin (all the Egyptians), or $\check{s} a ' b$ Mașr (the people of Egypt). His identifies his readers clearly in order to avoid any possible suspicion.

\section{3- The satirized (the target/ the object of attack)}

The target of his satire is not "an optional knowledge resource", as Attardo and Raskin (1991, p. 319) and Attardo (2001, p. 24) propose, but it is "central to satire" and a "mandatory element of satirical discourse" (Maslo, 2019, p. 240). Ṭāhir adopts an attitudinal personal perspective, targeting TWO categories, namely the Muslim Brotherhood and, first and foremost, Mursī and AbūIsmā' 1 ll's disciples. It reads, as stated on the cover page of his book: mahzūr bay'uh lil-ihwwān w-awlād Abū-Ismā '̄ll 'not to be sold for the Muslim Brotherhood or the sons of Abū-Ismā 'îl'. He likens his literary work to a commodity that is forbidden for those two groups. So, the cover page entails the two parties of the war against whom he engages, letting the readers know the author's opponents.

Furthermore, Țāhir's Dedication is publically and openly divulged, addressing all the rejecters of Mursī's regime and the Muslim Brotherhood as well, as in: ila kull al-räfidìn li-hukm aliḩwān wa-Mahammad Mursī ahdī kitābī hādā 'Mursī qalb alasad'. He lets the reader from the very beginning know that his recipients or the oriented audiences are those who stand against the MB's regime and those who reject the ruling of Mursī as the president of Egypt. He directly classifies his audiences or readers, excluding those who have no right to receive his work or to read it. The Dedication expresses the satirist's personal perspective that is 
Egyptian Political Satire: Parsing the Rhetoric of Parody in Īhāb Ṭāhir's Mursĩ qalb al-asad

Dr. Ahmad M. Ali

مجلة وادي النيل للاراسات والبحوث الإنسانية والاجتماعية والتربوية (مجلة علمية محكمة)

disclosed earlier on the cover page, targeting the MB and AbūIsmā 'îl's disciples.

\section{4- Medium}

4.1 Ṭāhir's language of satire

Gilbert Highet (2015) argues that most satirists create the feelings of resistance and 'protest' through the solicitous choice of their diction to provoke their readers' enthusiasm and to avoid boredom. The satirists' "[b]rutally direct phrases, taboo expressions, nauseating imagery, callous and crude slang ... are part of the vocabulary of almost every satirist" (p. 20). Țāhir, who represents 'the voice of his community' (Gray et al., 2009, p. 16), adopts a language, which is a written medium. Tāhir employs a combination of language varieties or levels. He mixes fuṣha al-turāt 'the traditional Standard Arabic', as in al-qatr allad̄i yasbiq al-ġayt 'a drop of rain that precedes the downpour' (p.16), with 'ammiyyit almutanawwirin 'vernacular of the enlightened', as in kifäyah 'alīh qarșit widn 'Lit. enough for him to get his ear pinched' (p. 59), and codeswitches to fuṣha al- 'așr 'the Standard Arabic of contemporary times', as in tafsìr siyādat al-ra'īs bi-anna al-ișyān al-madani balțagah 'the interpretation of His Highness, the president, that civil disobedience is barbaric' (p. 45), to 'transform' the language of the original into a language commonly known among the Egyptians (cf. Badawī, 1973; Sinatora, 2016).

Ṭāhir uses language as a 'weapon' against the target. His verbal attack or, rather, 'aggression' is on all kinds of vices in his political community. In this regard, Johnson (1945) outlines the vices or faults satire counteracts, as follows:

Satire everywhere attacks evil arrogant and triumphant, pride victorious and riding for a fall. It attacks those conventional respectabilities which are really hidden absurdities or vices blindly accepted by thoughtlessness, habit, or social custom. It attacks foolishness foolishly 
(ISSN : 2536 - 9555)

convinced that it makes sense, grinning and unrepentant in its folly. It attacks stuffed shirts, hypocrisies aping merit, puffed and blown-up insignificances like the frog trying to swell into an ox, counterfeit passing for true (p. 8).

\subsection{Narrative Strategy}

Ṭāhir's narratives, which are greatly confined to satirical commentary in the form of bullet phrases in the first part of his work and satirical dialogues in the second part, are mostly 'ammiyyah accompanied by recurrent occurrence of Egyptian Arabic. These narratives "reflect the characters' speech or thoughts in their own language and style ... through the use of Cairene Egyptian Arabic (CEA)" (Rosenbaum, 2012, p. 299). Țāhir introduces the text of satire in a language he likes most. It is an 'intersentential code-switching' (Mejdell, 2006, p. 414), which allows him to provide the reader with satirical comments through fuṣhāmmiyyah (Rosenbaum 2000) where "the fuṣha and 'ämmiyyah varieties are used in an alternating manner" (p. 71), for the sake of humor, as clearly shown in the following examples:

Fa-ana lā urìdu an u'akkir șafwak ayyuha al-qāri' al- 'azīz 'ala qalbī aw aqallib 'alīk al-mawāği '

(I do not want to bother you, my very dear reader, or to remind you of your endless pains.) (p. 16)

Mursī qalb al-asad allad̄i lam yatruk baladan 'ala harītat al-'ālam lam yadhab ilayha mutasawwilan yišhat 'alīna fìha

(Mursī, the lion's heart, who did not leave a country on the map without mendicancy, begging there on our behalf.) (p. 17)

Awwil ra' ’̄s yu 'allim ša 'buh al-ṣabr wa-țūl al-bāl - wa-țūlit al-bāl tiballag al-amal 
Egyptian Political Satire: Parsing the Rhetoric of Parody in Īhāb Ṭāhir's Mursĩ qalb al-asad

Dr. Ahmad M. Ali

مجلة وادي التيل للاراسات والبحوث الإنسانية والاجتماعية والتربوية (مجلة علمية محكمة)

(The first president who teaches his people patience and endurance, through which one's hope may come true.) (p. 24)

In the first example, fuṣha mirrors Țāhir's direct and formal address to his dearer readers, whereas 'ammiyyah (bold) breaks the ice between him and his readers and creates a friendly atmosphere. In the other two examples, fuṣha is interrupted by Țāhir's satirical comments in 'āmmiyyah (bold). Thus, Țāhir's style of writing based on fușa ammmiyyah enables the majority of his readers to enjoy reading his satirical writing according to the 'vocalization', i.e., the reading of words as they are written or spoken (Al- 'Isi1li, 2011, p. 9, as cited in Håland, 2017, p. 157). He believes that 'ammiyyah, as a sense of belonging, is the direct means of communication through which he approaches his readers easily with no obstacles or limits, bridging the gap of distances.

Then, Țāhir uses explanatory statements and synonymous phrases to criticize Mursī. For instance, he describes Mursī's violation of his vows, as follows: wa-Mursī lam yașun 'ahdahu wa-lam yafi bi-wa 'dihi 'and Mursī was not a man of his word and did not keep his promise' (p. 19). He adopts two resonant phrases of the same meaning, ending in rhyme words. He also uses explanatory phrases, such as $\boldsymbol{h} \bar{a} d i^{`}$ al-nās, hă $\bar{d} i^{`}$ al-Mașriyyin '(Mursīi is) deceiving people, deceiving the Egyptians' (p. 19).

\subsection{Offensive commentary}

Țāhir, as a satirist, directly and explicitly criticizes his opponent, the Muslim Brotherhood, in general, and Mursī, in particular, as he promises clearly in his Dedication. He does not conceal his bitter and offensive comments, as in ra'īs muntahī al-ṣalāhiyyah 'Lit. a president whose validity is expired' or yil ab fi hamāmit al-salām 'Lit., playing with one's dick' (p. 27). Instead, he openly voices abusive epithets, as in ra'is fi zaman al-tahyyis 'a president in the age of hallucination' (p. 23). Additionally, he announces from the 
(ISSN : 2536 - 9555)

very beginning in his satirical piece of art his hostility and hatred towards the other party he ridicules.

Țāhir expresses his own views directly through the dramatic plot. He expresses his views in which he believes through the characters participating in the events. Sometimes these views are offensively or vulgarly expressed. For example, Hamdīn replies aggressively to Mursī, when the latter converses with the former, saying: ana ba 'mil al-ṣahh 'I'm doing the right' (p. 86). Hamdīn replies, as follows:

Inta miš bi-ti mil al-ṣaḥh! inta bi-til'ab al-daḥh! wi-llī yil'ab al-daḥh may-uqulš aḥ! winta kidah ha-tuqūl aḥh yaMursì! ha-tuqūl aḥ! !

(You are not doing the right. You are playing carelessly, and he who plays carelessly should not say ouch. You, Mursī, in this way, will say ouch! You will say ouch.) (p.

86)

The vulgar language used in the dialogue here is functionally employed to express the complete refusal of the participant's speech. Hamdīn replies angrily to Mursī's speech; he uses rhyming speech, such as al-sahh (the right) and al-dahh (carelessness), including vulgar words, such as ahh (ouch), which implies offensive objection. The mixture of slang, classical and formal language in the dialogues of the characters adds a taste of special flavor felt by the reader. This is really a credit to Ṭāhir.

Țāhir also handles Mursī's personal traits negatively. For instance, he comments sarcastically on his al-ta'ta'ah fi nutq alinğiliziyyah 'stuttering in English' and sirr șuba 'uh al-šahìr 'the secret of his famous (index) finger (while talking in public)' ( $\mathrm{p}$. 61). Tāâir, in his psychological description of Mursī, uses rhyming phrases, ending in the letter mìm, such as katīr al-ibtisām, wabillayl là yanām, wa-in nām tazūruhu al-ahlāam 'recurrently smiling (face); sleepless at night, but if he sleeps, dreams visit him' (p. 62). 


\section{Egyptian Political Satire: Parsing the Rhetoric of Parody in Īhāb Țāhir's Mursĩ qalb al-asad}

Dr. Ahmad M. Ali

مجلة و ادي النيل للاراسات والبحوث الإنسانية والاجتماعية والتربوية (مجلة علمية محكمة)

In addition, Țāhir concludes the medical report of Doctor Hašabah, an imaginary character who psychologically treats Mursī, with very satirical proverbial rhyming expression, such as 'amal widn min țin wa-widn min 'ağìn 'having an ear of dust and another of dough', meaning turning a deaf ear.

\section{5- Tools (satirical techniques)}

\subsection{Double-Entendre}

The title of Tāhir's satirical work, which is Mursī qalb al-asad, is very significant; it has a double entendre, which is "a word, phrase, etc., that can be interpreted in two ways, esp. one having one meaning that is indelicate" (Thefreedictionary.com, n.d.). It functions as a type of humor as it indicates ambiguity or innuendos. To explain, the first half of the title implies the name of the hero of the work under study, Mursī. The second half of the title, which is qalb al-asad, implies a double entendre; it indicates the epithet of Mursī, whose heart is like the heart of the lion, referring to his courage. This interpretation is not meant in terms of the work under study. As for the second interpretation, which is intentionally meant, is the reference to the famous King of England, known as Richard the Lionheart. Starting from the title, Țāhir stimulates the readers' appetite to know the hidden connection between the title and its historical reference, and between the hero and the Norman King. Through a "single reference" (Thomas, 1986), Țāhir intends purposefully to "recall the context of the model', i.e., Richard the Lionheart, as a great military leader, and applies "that context to the new situation" (p. 177), i.e., Mursī, as a great failure and a lame-duck president on Țāhir's part. Thus, it is "a means of imparting great significance, or making connections or conveying ideas" satirically and indelicately sometimes (p. 177).

Additionally, Țāhir's work entails a very concise subtitle, i.e., fantazya siyasiyyah 'political fantasy', which, as its name signifies, is "a genre of fiction or other artistic work characterized by 
fanciful or supernatural elements" (Thefreedictionary.com, n.d.). $\mathrm{He}$ announces to the reader the type of his literary work $\mathrm{s} / \mathrm{he}$ is going to receive.

\subsection{Coded Iconic Message (Barthes 1977)}

This semiotic term is quoted from Roland Barthes' chapter entitled "Rhetoric of the Image" (1977), in which he proposes a 'conceptual framework' for decoding the 'word-and-image' signification through 'three messages': (1) a linguistic message (all the words included); (2) a coded-iconic message (the 'visual connotations' inherent in the design of the caricature/image); and (3) a non-coded iconic message ('the recognition of the identifiable objects' in the caricature/image) (pp. 36-7).

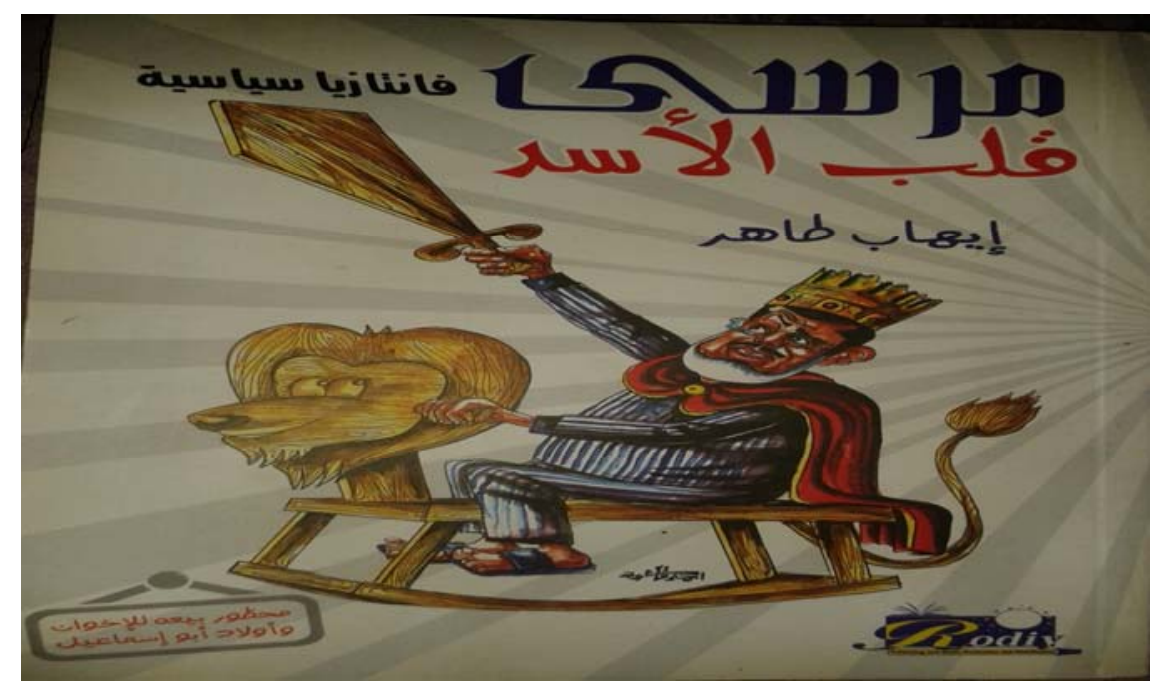

The 'linguistic message' encompasses all the words included in the cover page, such as the main title Mursi qalb al-asad, the sub-title fantazya siyasiyyah, the author's name Īhāb Ṭāhir, and the trigger warning notice mahzūr bay'uh lil-ihwān w-awlād AbūIsmā'ill. The main title Mursì qalb al-asad is proportionally designed. It is written in the upper right of the cover page. The word 'Mursis' is written in proportion to the second half of the title, qalb al-asad, which comes below 'Mursî', indicating that 'Mursī' 


\section{Egyptian Political Satire: Parsing the Rhetoric of Parody in Īhāb Ṭāhir's Mursī qalb al-asad}

Dr. Ahmad M. Ali

مجلة وادي النيل للاراسات والبحوث الإنسانية والاجتماعية والتربوية (مجلة علمية محكمة)

satirically equals qalb al-asad in the space of writing in the cover page.

The 'coded iconic message', it implies the 'visual connotations' inherent in the design of Mursis's caricature. The cover page, which consists of a text (the title and the sub-title of Țāhir's work) and an image (the caricature of Mursī), as explained above, is designed and well organized. The caricature is pictorial, and it has pictorial signs as well. It consists of two 'identifiable objects', Mursī and the wooden lion. The first object, i.e., Mursī, he is a pseudo-warrior, wearing pajamas and heading into battle with his glasses. He is portrayed frowning, indicating his pessimistic nature. His awkward gaze towards the sky implies his aspiration to capture Egypt. His neat moustache and trimmed white beard denote his Islamist background. With his fake crown and one eye wide open, he rides a relatively proportioned wooden lion with a long tail, save for the head, which is larger a bit than the body. Raising his large wooden sword up to the sky, he announces his readiness for any expected fight. He is also wearing a red dandling cloak and clogs.

The second object is a swing wooden lion, indicating his unsteady movements up and down. It is a comic caricature. Though it represents a serious situation, it is humorously drawn to be used as a prop, as if in a lunatic asylum. In other words, the "visual communication', delivered through the pictorial image, implies the underlying information the author intends to convey. Țāhir, in the second part of his satirical work, decodes the caricature inherent in the cover page, as follows:

Ahuh .. bi-albadlah dī .. bi-al-ddaqn dī .. bi-al-bașsah dī ..

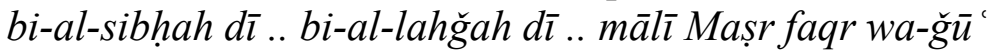

(Here, he is! (wearing) this suit, with this beard, with this weird look, (holding) these beads, (speaking) this accent ... spreading poverty and famine all over Egypt.) (p. 104) 
Among the visual associations is the lexical arrangement in the cover page. For example, in the upper left of the cover page, the phrase fantazya siyasiyyah is written in parallel to 'Mursī', the first half of the title. fantazya siyasiyyah is black in contrast to the word 'Mursī', which is dark blue. The word Mursī and the phrase fantazya siyasiyyah are horizontally lined together so that it is easily read: Mursī fantazya siyasiyyah 'Mursī is a political fantasy'. This is a possible interpretation of such arrangement. Mursī, a public figure and the president of Egypt at the time, is nothing but a 'political fantasy'. Additionally, the hero, who is wearing dark blue pajamas, indicating his dirty tricks in terms of the significance of colors in Egypt, holds a large wooden sword, above which the phrase fantazya siyasiyyah is written. Symbolically, it means: "The whole situation or tale is a fantazya siyasiyyah, and you, the reader, should not take it seriously."

The 'non-coded iconic message' connotes the 'recognition of the identifiable objects' in the caricature by the readers through the variety of colors. The font and the colors of the written text are purposefully employed as well. As for the colors, the dark blue one is of special significance to the author. The proper name of Mursī is written in the dark blue color. Also, Mursī's pajamas are colored dark blue. In the Egyptian culture, dark colors imply pessimism, sorrow, grief, and gloomy atmosphere. On the contrary, white indicates optimism, happiness, and goodness. Here, there is a mixture of colors that are professionally and intentionally employed. The dark blue color with which the name of Mursī is decorated recalls the common Egyptian saying ha-tištagalli fi alazraq 'will you work for me in blue!', balāwi zarqa 'blue tribulations', al- 'afarīt al-zurq 'blue demons', al-dibbān al-azraq 'blue flies'. It is of cultural specificity; it means 'stop using your own dirty tricks with me'. This, of course, foreshadows the wrongdoings of the hero of the satirical work. This is also a clever reminder of the forthcoming events embedded in the work itself. 


\section{Egyptian Political Satire: Parsing the Rhetoric of Parody in Īhāb Ṭāhir's Mursī qalb al-asad}

Dr. Ahmad M. Ali

مجلة وادي النيل للاراسات والبحوث الإنسانية والاجتماعية والتريوية (مجلة علمية محكمة)

On the other hand, the phrase qalb al-asad is ornamented with the red color, indicating the braveness of the lion, known as 'the king of the jungle'; it also connotes the blood of wars Richard the Lionheart shed. Similarly, the warning notice mahzūur bay'uh lil$i h w \bar{a} n$ wa-wläd Abü-Ismā $\bar{l} l$ is written in red, which fits the content of the notice; it functions as a stop sign for the readers so as to reflect upon it before proceeding to reading the book.

The last remark is inherent in the name of the author. It is written in dark blue, indicating the use of dirty tricks as opposed to Mursī's. His name is shown above the crown of the hero of his satirical work. As for the colors of the lion, the cloak and the crown, they seem to be normal and natural.

\subsection{Satirical epithets}

After stating the purpose behind his book, Țāhir promises his readers that he will stop reminding them of the abuses of Mursì's regime, but later he swallows his words. He sarcastically describes Mursī as qalb al-asad 'the lion's heart', al-'àlim al-ğalīl 'the reverend scholar', and al-iqtișādi al-iḩwānì 'the MB economist', who invented a new branch of economics based on mendacity. Mursī is sarcastically portrayed as one of al- 'ulama al al-qalà il alaf $\underline{\underline{a}} \bar{a} \underline{d}$ 'the few outstanding scholars' in economics, to whom yušarū ilayhim bi-al-banān 'fingers point or refer', as he introduced the economics of begging, which is regarded as one of the most acknowledged theories of economics in the world. It is the theory of market or supply and demand. In this context, Tāhir compares Mursī's economic inventions or novelty to Thomas Malthus (1766-1834), the renowned English economist. Also, Mursī is nicknamed al-hidīwī 'khedive', similar to Khedive Ismā 'īl due to the domestic and the external growing debts of Egypt.

Furthermore, Mursī has been dramatically addressed in the Egyptian colloquial Arabic informally and in an unfriendly manner, as in irğa' yā 'amm al-hağğ inta ta 'abtina ma' ăk 'come 
(ISSN : 2536 - 9555)

back, old folk! You caused us a lot of troubles!' inta wașșaltina limarhalit nafäd [sic] șabrina 'you pushed us to impatience' (p. 42), and hudha min qașirha ya Mursī 'be straightforward / get to the point, Mursī' (p. 43). The form of direct address is functionally employed through the vocative case, which is gradually used for the person being addressed, changing from $y \bar{a}$ 'amm al-hağğ into inta, and $y \bar{a}$ Mursī. In some other contexts, Mursī has been gently and formally addressed, as in min wikālit NASA ila al-ra' '̄s Mahammad Mursi 'from NASA Agency to the president Muhammad Mursī’ (p. 41). Respect and reverence of address is exemplified in calling him 'the president'. Gradually, al-ra' $\bar{l} s$ is stripped of his title, and, finally, he became a code and of no importance, as in min wikâlit NASA ila al-'amīl 1313 al-mad' $\bar{u}$ 'from NASA Agency to the agent no. 1313, the so-called' (p. 42).

\subsection{Satirical sub-titles}

Țâhir divides the first part of his book into 16 chapters, which epitomize the wrongdoings of Mursī and the MB. The first four chapters revolve around the achievements of the president Mursī from the point of view of Mursì's exponents. These chapters are entitled inğazāt ra'īs fì zaman al-tahyyis 'the achievements of a president in the age of hallucination', inğazāt ra' 'is al-ğumhüriyyah fi al- 'uqül al-ihwwäniyyah 'the achievements of the president of the republic in the brains of the MBs', inğazāt Mursi qalb al-asad 'the achievements of Mursī, the lion's heart', and inğazāt ra' '̄s fí šahruh al-tāsi" 'the achievements of a president in his ninth month'. The four sub-titles are satirical; they all focus on the blunders of Mursī. These subtitles are initiated with the indefinite word inğazāt and followed by satirical complements, such as $r a{ }^{\prime} \bar{l} s$ fì zaman al-tahyyis, ra'īs al-ğumhūriyyah fì al-'uqūl alihwāniyyah, Mursì qalb al-asad and ra'šs fì šahruh al-tāsi'. Three subtitles of them include an indefinite epithet, i.e., $r a ' s s$, which implies belittlement and deprecation of Mursī, who is a mere president. Additionally, the phrases $f \grave{i}$ zaman al-tahyyis and $f \grave{\imath}$ al'uqūl al-ihwāniyyah deny the achievements Mursī, which exist only in the age of delusions, and which exist only in the brains of 


\section{Egyptian Political Satire: Parsing the Rhetoric of Parody in Īhāb Țāhir's Mursĩ qalb al-asad}

Dr. Ahmad M. Ali

مجلة وادي النيل للاراسات والبحوث الإنسانية والاجتماعية والتربوية (مجلة علمية محكمة)

the MB; and the phrases qalb al-asad and fí šahruh al-tāsi 'imply satirical allusions; the former alludes to Richard the Lionheart, whereas the latter, the period of pregnancy, which is contradictory to his nature as a man. To explain, $f \grave{i} \check{s}$ ahruh al-tāsi figuratively is a satirical phrase, which implies the hard times Egypt went through during Mursī's term; it is a period similar to the period of pregnancy, during which a woman suffers pain. Here, Țāhir likens Egypt, which suffers from Mursī’s blunders, to a pregnant woman, who suffers from the pains of childbirth.

\subsection{Dehumanized personification of the satirized}

In a chapter entitled min wikälit NASA ila Mahammad Mursī 'from NASA Agency to Muhammad Mursī’ (p. 41), Țāhir makes fun of Mursī, who is transformed into a robot, receiving coded messages from the spacecraft. Mursī here is dehumanized; he became a mere machine, not a human being, as Țāhir considers him an object powered by the doer, al-Muršid, who is represented by NASA Agency, which found out ba 'ḍ al- 'uyūb al-fanniyyah al-hāsșah bibarmağitkum 'some technical defects in your programming'. This chapter consists of three urgent appeals, targeting Mursī or Agent 1313, as Țāhir calls him. All of them are directed to Mursī to change his mind and to get back to the spacecraft before the discharge of his battery; they call upon him to give up the current struggle in Egypt and to relinquish authority peacefully without resistance. The tone of address of the urgent appeals is serious, and the message is warning and threatening to Mursī. The first and the second appeals quietly advise him to listen to the spacecraft twice. The appeals to come back are repeated 4 times, but in different wording, as in rağa 'an al- 'awdah ila markabat al-fadà' fawran 'please return to the spacecraft immediately' and rağ $\bar{a}$ ' an ihdar ilayna fawran 'please come to us without delay' in the first appeal, and rağ $\bar{a}$ 'an al-'awdah ilaynā fawran 'please return to us immediately' and lida narğ $\bar{u}$ al- 'awdah fawran 'so, we beg you return immediately' (p. 42) in the second appeal. The two warning messages urge him to abandon his home in al-Tağammu' 
مجلة وادي النيل للاراسات والبحوث الإنسانية والاجتماعية والتربوية (مجلة علمية محكمة)

(ISSN : 2536 - 9555)

Compound or his whereabouts, the headquarters of the MB in alMuqattam District (p. 42), as his resistance or reluctance will lead to bad consequences, which may devastate not only you, but it may extend to include your people and the whole country (p. 41).

\subsection{Imaginary Scenarios}

In one of Țāhir's satirical chapters entitled Mursī lil-Muršid: intū labbistūnī fì hịṭah! 'Mursī to al-Muršid: 'You entrapped me!', he creates a down to earth scene out of his own imagination that, in the end, turns to be a mere dream or a nightmare of Mursī. Skillfully, Țāhir depicts the potential relationships between the members of the MB according to his own view. On his part, Tāhir sympathizes with Mursī, who is considered to be the victim of the $\mathrm{MB}$, and the subtitle is functionally employed to show his sympathy with him, even if it seems partial or temporary. Taahir believes that Mursī is not up to assume rule of Egypt; it is enough for him to bring up his own children and to take care of his household. This fact in which Țāhir believes is clearly expressed on Mursī's tongue in this chapter; he converses with the gathering, saying: intū labbistūñ̄ fì hịtah! ana kan mālì wi-māl hukm Mașr? ana kifāyah 'alayyah ahkum ahl bītī. He blames Mursī for nominating himself to be the president of Egypt, which is not kum hamadah or kafr šukr (small rural villages in Egypt). His blame is admitted by Mursī, who regrets being the president of Egypt, accusing himself of getting mad; he says: ana itğannint lamma wäfiqtukum innī araššah nafsī makān al-Šătir 'I got crazy when I listened to you and nominated myself instead of al-Šațir' (p. 53).

\subsection{Humor-induced dialogue}

Țāhir's script generally abounds in humor, especially in a chapter entitled Mursī lil-Muršid: intū labbistūñ̄ fì hịtah! "Mursī to alMuršid: 'You entrapped me!'” The characters look as if they are in a real polemic war; they act and react in response aggressively. For example, Mursī replies aggressively to al-Muršid, who attempts to motivate Mursī and to encourage him to assume his term in office, saying: inta ahl laha yā Mursī 'you are up to it, Mursī' (p. 52). 


\section{Egyptian Political Satire: Parsing the Rhetoric of Parody in Īhāb Țāhir's Mursī qalb al-asad}

Dr. Ahmad M. Ali

مجلة وادي النيل للاراسات والبحوث الإنسانية والاجتماعية والتربوية (مجلة علمية محكمة)

Mursī replies angrily: ahl mīn yaba da-al-nās kalit bi-wǐ̌š̄ min hikāyit ahlī wa- 'aširtī dī 'Are you serious, pop? I cannot face people because of the issue of my family and kinsfolk' (p. 52). Also, a very humorous but serious dialogue between Mursī and Qandīl is skillfully written; Mursī accuses Qandīl of failure,

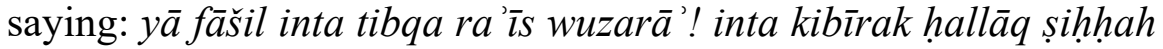
'Oh, failure! You, you wanna be a prime minister! You fit to be only a rural barber' (p. 52). He makes fun of him and admits his failure before the gathering; he despises the role he performs; he is up to be, according to him, halla $q$ sihhah, a minor barber job practiced at home in the rural society. Hallāq al-sihhah is also known as mizayyin in Upper Egypt; he is a male barber, "whose job is not limited to haircuts and shaves; he is also pharmacist, gives injections, does venesection (blood-letting), circumcises"; he is "responsible for sanitation, and at times has other medical duties too, regardless of whether or not he has the qualifications" (Baer, 2016, p. 167). In response to Mursī's insult, Qandīl retaliates for his offense; he says: intū qultūl h̆ hăğah ana ma- 'amaltahāšs? ana barbut al-humār matrah ma-yu 'ūz al-humāar 'Am I to blame? I am always at your service; I tie the donkey where the donkey likes' ( $p$. 53). There is a linguistic deviation in the maxim that is well known among the Egyptians. Qandīl makes a little change in this maxim; he intentionally employs the word al-humār 'donkey', the second one, instead of săhibuh 'his owner', the original. This humorous response evokes satirically laughter of the reader.

Again, Mursī's reproach to al-Biltāğ $\bar{~}$ is full of humor, implying sarcasm, as in 'ayyiz tibqa wazìr dāhiliyyah marrah wahdah? ... ibqa itgatța kuwayyis yā Biltāăg $\bar{l}$ 'you wanna be a foreign minister all at once? ... cover yourself well while sleeping, Biltāğì’ (p. 53). Mursī’s ridicule of Qandīl arouses one's laughter, as the phrase ibqa itgatta kuwayyis implies an offensive indication; it means that 'your buttocks are uncovered while sleeping'. Egyptians believe that one dreams when one's buttocks are 
(ISSN : 2536 - 9555)

uncovered. It is said to make fun of those who say nonsense or foretell illogical or strange dreams.

\subsection{Portrayal of interpersonal relationships}

Țāhir shows the strong relationship specifically between al-Šāțir and al-Muršid. It is obvious through the formidable speech of alMuršid with al-Šățir, who is kindly and gently addressed by alMuršid. He has got the title of muhandis al-ğamā 'ah 'the party's engineer', who is 'brave' and 'callous'. He does not believe in sentiments, which 'may yield to considerable repercussions' and have no 'place in political wars' (p. 57). Words and phrases of compliment are frequently used by al-Muršid to al-Šătir. For example, inta dimā $\dot{g}$ y $\bar{a}$ Šățir 'you're a genius, Šățir', inta halīftī fì maktab al-iršăd 'you're my vicegerent in the office of guidance', inta qalbak mayyit yā Šāțir 'you're callous, Šățir', and inta ibn̄ yā Šățir 'you're my son, Šătir' are uttered to describe the character of al-Šatịir and his standing role in al-ğamā 'ah 'the Group'. In turn, al-Muršid is formally and respectfully addressed by al-Šāțir. For example, various titles are given to al-Muršid, like fadiltak 'your highness', ma 'ālīk 'your majesty', ǧanābak 'your nobility', sa 'adtak 'your excellency', yā fandim 'O, Sir', fahamtak 'your dignity', and sumuwwak 'your highness'. Through this cluster of titles and formidable father-son relationship, Tāhir unveils the hidden secrets among the members of the MB and their Muršid to the reader.

\subsection{Satirical parody of al-Taḥrir Square}

In a chapter entitled huna maydān al-Tahrir 'here's al-Tahrir Square' (p. 69), Țāhir creates a satirical parody of Taḥrir Square, where demonstrations were held. He creates a story of two characters, Îhāb, a husband whose name is similar to that of the author of this work, and Gāah, his wife. Țāhir narrates a very simple story; it deals with the husband's very simple domestic demands; he asks his wife gently to prepare hallit maḥš̄ kurumb 'a pot of stuffed cabbage', șiniyyit kīk bil-zabād 'a tray of cake with yoghurt' and baby dull iswid 'black babydoll'. He frequently 


\section{Egyptian Political Satire: Parsing the Rhetoric of Parody in Īhāb Țāhir's Mursĩ qalb al-asad}

Dr. Ahmad M. Ali

مجلة وادي النيل للارسات والبحوث الإنسانية والاجتماعية والتربوية (مجلة علمية محكمة)

repeated his demands; he never gave up; he kept insisting on his demands though he was rebuffed. He used every possible means to convince her, but in vain. When he failed to persuade her to carry out his demands, he started to think of another possible solution. Finally, he decided to campaign and demonstrate at home, imitating what was happening in al-Tahrir Square. On Ġādah's returning home with company, she opened the door of her flat, she found her husband half-naked, sitting under a large blue tent. Feeling embarrassed, she excused her friends and begged her husband, telling him that all his demands will be carried out. Tāhir trusted her and ended his sit-in, taking down his tent, letting her and her friends come in. A few days later, her husband went home with a friend; he found his wife imitating the same trick he did. She campaigned and erected a large blue tent similar to his. He had to leave his friend at the door, begging her to remove her tent and stop demonstrating. She conditions on fulfilment of his demand. She told him he should carry out her demands first. He gave in to the pressure of her demands, which included an air conditioner, a 41-inch television screen, and an increase in the monthly home budget. She gave him a lesson at the end of their tit-for-tat tricks; she told him that she can demonstrate and campaign the same way he does; days are ups and downs; she is perfect in retaliation. Here, Țāhir creates a symbolic story by which he comments satirically on the funny demonstrations people make and trivial demands they ask for.

\subsection{Bullet Phrases}

Țāhir uses bullet phrases, which are very concise and precise; they are intentionally employed to highlight significant information and key words, targeting satirically the achievements of Mursī, especially in the early period of his presidency. Throughout the first part of his book, which revolves around the so-called achievements of Mursī, Țāhir uses very concise phrases, describing satirically Mursì's personal and public character. For example, in a chapter entitled $r a '$ 'ss fi zaman al-tahyyis 'a president in the age of 
(ISSN : 2536 - 9555)

hallucination', Țāhir uses definitional phrases, which are long a little bit, except for awwil ra'șs lìh $r a$ 's̄s 'the first president to have a president' and awwil ra'šs multahī 'the first president with beard'. He criticizes Mursī's guards, who accompany him in his prayers at mosques; he says: awwil ra'ìs yaš ur bil-hüf wi-'adam al-amān fì buyūt Allāh wa-yuṣallì bi-ḩarasuh 'the first president who feels frightened and insecure at the houses of God, performing prayers in the company of his guards'. That is why he yusalli kull ğum 'ah fì masğid gì $\bar{r}$ al-āhar 'performing every Friday prayers in every other mosque' (p. 23). He makes fun of his prime minister, who talks offensively about the styles of breastfeeding, as follows: awwil ra'īs ra'îs-wuzarā'uh yatahaddat 'an asālīb al-rid̄a 'ah wilaban al-sarsūb 'the first president whose prime minister talks about the methods of breastfeeding and foremilk' (p. 23). Professionally, Țāhir employs the language and style of commercials that depend basically on brevity and succinctness.

\subsection{Axiomatic Phrases}

Țāhir uses axiomatic phrases, i.e., 'self-evident truths that require no proof' (Thefreedictionary.com, n.d.), in a chapter entitled inğazāt ra's̄s al-ğumhūriyyah fì al-'uqūl al-ihwāniyyah 'the achievements of the president of the republic in the brains of the MBs'. These phrases are a set of natural biological behavior. They are mentioned as items in a personal résumé of Mursī. Țāhir initiates this chapter with Mursī's name, i.e., Mahammad. He has boys and girls; he can read and write; he does not drink tea or coffee; he does not smoke; he prays the 5 daily prayers, including the optional ones. Tāhir satirically opts for a set of axiomatic phrases to complete Mursī's curriculum vitae. For example, Tāhir considers Mursī's natural conduct as to be distinctive features; he says, lamma bi-uǧūe bi-yākul 'when he feels hungry, he eats', lamma bi-yi 'taf bi-yišrab 'when he feels thirsty, he drinks', lamma bi-yinām bi-yigammad 'inuh 'when he sleeps, he closes his eyes', and yartadī al-malābis al-šitwiyyah fí fașl al-šitā' wal-malābis alsayfiyyah fi fașl al-șayf 'he wears winter clothes in winter and summer clothes in summer'. He uses these axiomatic phrases as a 


\section{Egyptian Political Satire: Parsing the Rhetoric of Parody in Īhāb Țāhir's Mursī qalb al-asad}

Dr. Ahmad M. Ali

مجلة وادي النيل للاراسات والبحوث الإنسانية والاجتماعية والتربوية (مجلة علمية محكمة)

non-verbal humor, making fun of Mursī and underestimating his presidency.

\subsection{Semantic prosody}

Ṭāhir is good at employing semantic prosody, meaning 'negative or positive associations'. His satirical book is rich in both kinds of associations, but negative or satirical associations are repeatedly used in his work, as its optimal goal is to amuse the reader and to defame Mursī and the MB. Tāhir, for example, criticizes the type of economy Mursī has invented, the economy of begging. He considers Mursī as one of the few genius scholars to whom fingers point or refer, indicating his worldwide fame. His choice of a few positive association of words, i.e., al- 'ulamā' 'scholars' followed by al-qala' $i l$ 'few', which is followed by the positive attribute alaf $\underline{d} \bar{a} \underline{d}$ 'outstanding', in a satirical context transforms these positive associations into negative ones. This simply means that his usage is ironic. His satirical goal extends to use humorous description of Mursī; he uses another positive phrase modifying the previous description, i.e., al-ladīna yušarū ilayhim bil-banān 'to whom fingers point'.

In addition, the phrase timsah ğ ḡḥi is supposedly uttered by alMuršid to al-Katatnī, who was the president of the Egyptian People's Assembly and a senior leader in the MB. It is taken from the dialogue between them. The collocated words of timsah ğ $\bar{u} h \bar{\imath}$ 'baize' imply "flattery, toadying, buttering-up" (Badawī and Hinds, 1986, p. 180). It is usually said when you fail to get what you desire from anyone by fair methods, except for 'sincere praise' and 'honeyed words'.

As for the phrase fašalak al- $\underline{d} a r \bar{l}^{\prime}$, it is supposedly uttered by Mursī to Hišām Qandīl in the script. It is employed by Țāhir to describe the state of failure Egypt went through during Qandīl's office as a prime minister. This phrase consists of a noun fašalak plus a modifier al- $\underline{d} a r \bar{\imath}$ '. It means 'your complete failure'. This 
(ISSN : 2536 - 9555)

collocated combination reflects, from Țāhir's point of view, the complete failure Egypt witnessed through Mursī's regime and his prime minister, Qandīl, as well. It has a negative connotation.

The phrases balāš tawadu' inta dimāg y ya Šătir include a set of positive associations. They are two phrases: balāš tawaḍ ' and inta dima $\bar{a} \dot{g} y \bar{a}$ S̆atiti. The former is usually said in a situation when the speaker shows expressive modesty and humbleness in his speech towards the listener. It consists of balās̆, a colloquial negative particle, meaning 'do not', and tawadu', meaning 'modesty'. It means 'Do not underestimate yourself! You are capable of doing more than you can ever imagine'. As for inta dimāg $y \bar{a}$ S̆attir, it is of positive and negative associations. It depends upon the given context. For example, it could be interpreted as 'having diarrhea of the mouth', implying 'constant talking without thinking'. Yã Šătir, in this regard, implies linguistically 'an anonymous vocative', but it refers to the addressee in reality, the known vocative, Hayrat alŠătir. It can be used ironically to mean 'not so bright'. In addition, it could be interpreted in concordance with the given context here, as follows: 'Oh! Šațir, you are genius!'

The phrase ğam'it al-hankah bi-ğumhuriyyit Maṣr alihwānkiyyah has a set of negative associations. Taahir initiates his narration on the qualifications of Dr Hašabah (Lit., a piece of wood), whose name is very satirical, as it arouses one's laughter. $\mathrm{He}$ mentions the name of the university from which he has graduated, i.e., ğam it al-hankah, which is a colloquial equivalent to a 'lunatic asylum'. Al-hankah has other Egyptian colloquial Arabic equivalents, such as mustašfa al-mağad̄itb, mustašfa almağanīn, mustašfa al-'abbasiyyah and al-muristān. Thus, ğam 'it al-hankah has a negative association; it indicates that Mursì's private physician is not abnormal man; he is insane or mad. Tāhir continues his narration on the qualifications of Dr Hašabah; he specifies the location of ğam'it al-hankah, which lies in ğumhuriyyit Mașr al-ihwwankiyyah. Of course, it is not real; it is a fabricated country or res publica. It has a negative association, as 


\section{Egyptian Political Satire: Parsing the Rhetoric of Parody in Īhāb Țāhir's Mursĩ qalb al-asad}

Dr. Ahmad M. Ali

مجلة وادي النيل للاراسات والبحوث الإنسانية والاجتماعية والتربوية (مجلة علمية محكمة)

al-ihwankiyyah is a newly coined term of the $\mathrm{MB}$, who transformed Egypt, the Arab Republic, into the Republic of the MB according to Ṭāhir's view.

Through the phrase al-tamkīn al-ihwān̄ī min mafāṣil aldawlah, Țāhir satirically comments on the blunders of Mursī. In this regard, he describes the hoggishness and greediness of Mursī, the president of Egypt, who has an excessive desire for seizing and usurping Egypt. So, this phrase has two negative associations, which are al-tamkīn al-ihwwān $\bar{\imath}$ and mafășil al-dawlah, which acquired its negative association from the full control of the MB over Egypt. Al-tamkin in general has a positive connotation, but its positive connotation turned into negative connotation through its combination with the attribute of al-ihwānī. Al-tamkin in general means 'enablement', 'empowering', or 'establishment', but when it is collocated with al-ihwānin, it acquired a new interpretation explained in the following phrase through which Țāhir clarifies the type of enablement, i.e., mafășil al-dawlah 'joints of the country'. It is a colloquial expression, meaning 'the country's bodies or entities'. So, the whole phrase means 'the MB's seizure of Egypt's bodies'.

\subsection{Lexical parallelism}

Țāhir includes a separate chapter in the first part of his satirical

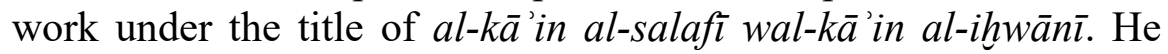
makes a humorous comparison between the two parties. The subtitle implies degradation and ridicule, especially the word $a l-k \bar{a}$ in 'being', which lacks human characteristics. The comparison is well organized and well balanced. Additionally, it is precise and concise, as Țāhir uses concise definitions and satirical epithets. Sometimes, he resorts to explanatory definitions annotated with maxims. Logically, he initiates his comparison through focusing on $a l-k \bar{a}$ 'in al-ihwānn, the core of his book. For example, Tâhir

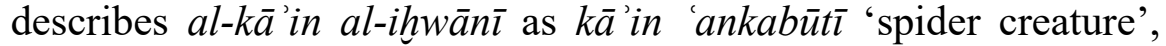
whereas al-kā'in al-salafí as $k \bar{a}$ 'in 'aqrabì 'scorpion creature'. 
(ISSN : 2536 - 9555)

Țāhir does not choose descriptions haphazardly. He uses satirical epithets, but they are significant and indicative as well. Although both spiders and scorpions are 'arachnids', having eight legs, each class has its own features. In TTāhir's view, both the MB and alsalafiyyin 'Islamists' look like the creatures he likens them to; they have the same features. Spiders, for instance, are of various 'sizes', ranging from 'tiny' to 'massive'. Spiders can 'jump' when necessary; the 'vast majority' of them cause no 'harm'; they are of great importance to humans, as they get rid of 'insects' and 'pests' that destroy 'crops' and affect 'agriculture'. They are 'carnivorous', 'trapping flies and other insects in their webs', which are made of 'silk', or 'hunting them down'. They use their strong webs for many 'purposes'; they use them to 'climb', to 'tether themselves for safety' in case of danger, to 'create egg sacs', to 'wrap up prey', or to 'make nests'. Losing their 'habitat' is a great danger (nationalgeographic.com, n.d.). Similarly, as Țâhir claims, the MB has various categories and classes. They spread all over the world. They have an 'issue' to defend and die for. They are too quiet to get angry, controlling their actions and reactions; they act maliciously, like foxes. They do not hate others, but they ridicule them implicitly, as they wish they could oppress, remove, or destroy others (p. 65). They feel oppressed all the time. They flatter to persuade and bargain to get the least they could; they believe firmly in the maxim that says, mala $y u$ 'had $\left[\right.$ sic] kulluh la yutrak kulluh $[\text { sic }]^{8}$ "what cannot be taken at once, should not be left at once' (p. 65). Humorously, Țāhir inserts some satirical collocated associations. For example, he describes them as $k \bar{a}$ 'in 'ankabütī 'spider creature', qurș islāmī mudmağ 'compact Islamic disk', nushah uriğināl 'original copy', and muslim kağwal 'casual Muslim', for they do not have beard or wear Islamic uniform.

Scorpions are 'poisonous' and very dangerous; they use their 'poison' as a means of self-defense against 'predators' and hunting their 'preys' (nationalgeographic.com, n.d.). Țāhir, in his simile, believes that Islamists are more or less like the scorpions. They are intolerant and overzealous for their religion. They do not 
Egyptian Political Satire: Parsing the Rhetoric of Parody in Īhāb Ṭāhir's Mursĩ qalb al-asad

Dr. Ahmad M. Ali

مجلة وادي النيل للاراسات والبحوث الإنسانية والاجتماعية والتربوية (مجلة علمية محكمة)

respect others or accept their behaviors; they are moody, aggressive, and disorganized. They are frequently marrying, twice, thrice, etc. They are muslim kilāsīkī 'classic Muslim', as they have beard and have no moustache. Finally, Țāhir comments on the bad relationship between the two creatures. He says that they are on bad terms; there is a hidden hostility and hatred in their common interests (pp. 66-7).

\subsection{Idiomatic dramatized parody}

Țāhir's satirical style of writing abounds in idiomatic parodies, which mean reconsideration of old or common Egyptian proverbs, sayings, or maxims. Tāahir quotes these recurrent patterns and modifies them according to the given context. The replacement of words does not exceed one or two in number, recurrently used in the most famous Egyptian sayings in the masterpieces of cinematic works. This style of writing is specifically shown in a separate chapter entitled $\bar{a} l \bar{u}$ 'an al-nahdah 'they talked about the Renaissance (project of development)', which is rich in idiomatic parodies. Throughout the following famous utterances on the tongue of famous actors and actresses, Țāhir focuses only on one word, i.e., al-nahdah, which replaces a focal word in the original. Professionally, Tāhir was fortunate in his choice of the rechangeable alternatives. He accurately chose the utterances and skillfully replaced the intended lexical items, quoting the sayer of these famous statements. For instance, he chooses one of the most sayings of the late Egyptian actress, Mārī Munīb, and transforms farhah 'joy' into nahḍh (in bold), as in yā nahdah mā tammit hadhā al-i்urāb wi-tār (Alas! The renaissance has not been yet achieved, as the crow took it away) (p. 71). Also, the saying of the late Egyptian actor, Abdel-Fattāh al-Qușarī, which is yā șafāyh alnahḍah al-sayhah yā qawālib al-zibdah al-nayhah (How the jerry cans of renaissance are melted! How the molds of butter are spread!), depends basically on the word al-zibbdah 'butter', which is replaced by al-nahdah 'the renaissance' in the first part of the saying. The late Egyptian actor, Tawfĩq al-Diqn's most famous 
مجلة وادي النيل للاراسات والبحوث الإنسانية والاجتماعية والتربوية (مجلة علمية محكمة)

(ISSN : 2536 - 9555)

utterance is ahla min al-šaraf mafǐš (Nothing is better than one's honor), in which šaraf 'honor' is replaced by al-nahdah. Iw'a algambari yu'uddak (Beware of the shrimp!) is a famous utterance by the Egyptian actress, Nadyah al-Ǧendī, where al- ğambarī 'shrimp' is replaced by al-nahdah. Tismahīlī bi-al-raqaṣah dī (Would you please let me dance with you?) is a famous utterance by the late actor, Istifān Rustī, where bi-al-raqașah 'one dance' is interchanged by al-nahdah. Finally, Yūsuf Wahbah, the late famous Egyptian actor, uttered a famous saying, which became commonly used till today by the Egyptians; it is šaraf al-bint zayy 'ūd al-kabrìt maywalla 'š gì marrah wahdah (a girl's honor is like a matchstick lit only once), where šaraf al-bint 'a girl's honor' is replaced by al-nahdah. Thus, this technique creates a friendly atmosphere between the reader and the text, dissolving into laughter.

\subsection{Dramatized phraseologies}

Borrowing dramatic phrases from the original is one of the salient features of Țāhir's fantasy movies. Țāhir skillfully deploys exact phrases and extracts from the original in each movie of his own selection. He attempts to remind the reader of the original's atmosphere, arousing his laughter and smile. For example, Tāahir borrows some phrases from the movie al-Nāsir Șalah al-Dīn in his fantasy movie Mursī qalb al-asad, such as wa-lākinnakum taḥriquna ag̣șān al-zaytūn, a famous phrase uttered by Salaḥ al$\operatorname{Din}$ in the original to be imitated by Mursī. Here, the previous phrase is functionally employed by Țāhir. The context in which it is used seems to be logical and effective. For example, he paves the way for the reader to make a link between the borrowed dramatic words or phrases and the previous dialogue, which seems as if it is taken from the original. Here, the phrase wa-lakkinnakum tahriquna a $\dot{g} s \bar{a} n$ al-zaytūn is uttered by Mursī in response to the comment of al-Barad' 1 , who satirically criticizes the seizure of Egypt, represented in some cities, by the MB. He says: damīr ğabhit alinqāo lā yațma'in wa-Mașr Manšiyyit al-Ṣadr wal-Dimirdāš waKubrī al-Qubbah wa-Saraya al-Qubbah wa-Hadā'iq al-Zaytūn fi 


\section{Egyptian Political Satire: Parsing the Rhetoric of Parody in Īhāb Țāhir's Mursĩ qalb al-asad}

Dr. Ahmad M. Ali

$$
\text { مجلة وادي التيل لللاراسات والبحوث الإنسانية والاجتماعية والتربوية (مجلة علمية محكمة) }
$$

$\bar{z} y d$ ihwäniyyah (The conscience of the Salvation's Front does not feel secure as long as Egypt, Manšiyyit al-Ṣadr, al-Dimirdāš, Kubrī al-Qubbah, Saraya al-Qubbah, and the gardens of olives are still in

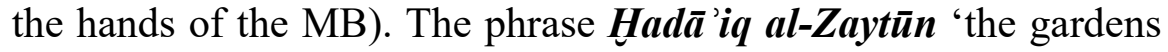
of olives' is the key that stimulated Țāhir to employ the borrowed phrase, i.e., wa-lākinnakum tahriquna ağșān al-zaytūn (but you are burning the olive branches), which arouses the reader's laughter, being fully aware of the original, and his surprise as well.

The process of borrowing dramatic words or phrases is functionally employed by Tāhir thoroughly in his fantasy movies through mixing seriousness with banter. For example, Hamdinn imitates the words of al-Nāssir Șalah al-Dīn targeting Mursī; he borrows some of his words and mingles them with good-humored ones; he says: li-takūn ra'īsan 'ala Mașr tabhat 'an 'anāqìd al-full wal-yasmīn wa-ațbāq al-ruzz bi-al-laban wa-akwāb al-qirfah bi-alganzabil (Let you be the president of Egypt, who is looking for the bunches of jasmine, the plates of rice with milk, and the cups of cinnamon with ginger) (p. 77). The borrowed phrase is tabhat 'an 'anāqìd al-full wal-yasmīn (looking for the bunches of jasmine) is humorously mingled with the phrase of wa-atbāq al-ruzz bi-allaban wa-akwāb al-qirfah bi-al-ğanzabīl (the plates of rice with milk, and the cups of cinnamon with ginger). Shortly, Hamdīn switches his speech to adopt some words of al-Nāșir Șalah al-Dīn again, as in anta turīdu al-harb li-yakun mā turìd (Let it be war as you wish). This kind of mixture keeps the reader aware of the original while reading the fictional version.

Țāhir also resorts to surprising his readers in his script. $\mathrm{He}$ borrows words or phrases from the original, inserting words that are linguistically deviated. Shifting in the arrangement of the collocated words affects positively the attitudinal linear thought of the reader, who feels surprised by such a combination. For example, Mursī replies to the gathering, including Hamdīn, al$\operatorname{Barad}^{\prime} \overline{1}$ and al-Badawi, using the phrase ta'attarat sayyāratī al- 
(ISSN : 2536 - 9555)

marsìdis in the sequence of the borrowed phrases of al-Nāșir Șalạ̣ al-Dīn, as follows: Mursī yataqaddam ilaykum rāğiyan an taqbalū yadahu al-mamdūdah bi-al-salām fal-natahāwar li-nağlis 'ala māidat al-hiwār fa-fí al-tarīq ilaykum ta attarat sayyārat̄̄ almarsīdis (Mursī approaches you, hoping you accept his hands outstretched towards peace; let's sit together on the table of dialogue; my Mercedes car stumbled while driving to you) (p. 78). This shift interrupts the linear thought of the reader, who consciously reads the dialogue, retrieving the original text. The awkward phrase ta 'attarat sayyāratī al-marsīdis has a linguistic deviation; the word ta 'attara means to 'stumble' or to 'trip', i.e., "to miss one's step in walking or running" (Thefreedictionary.com, n.d.). It collocates with humans and animals, as in ta attara lisānuh, meaning 'one's tongue stammered or stuttered', or 'atarara al-faras (Almaany.com, n.d.), meaning 'one's horse stumbled or slipped'. As explained, the awkward phrase ta 'attarat sayyāratī almarsìidis, which literally means 'my Mercedes car stumbled', pays the reader's attention to the witty excuse of Mursī.

\subsection{Satirical dramatic and cultural allusions}

Țāhir employs some satirical dramatic allusions in his satirical work to break the seriousness of the events and to make comic relief. For instance, al-Barad ' $\overline{1}$, in his conversation with Mursī, replies satirically to him; he intentionally uses the phrase qandīl umm Hāšim ${ }^{9}$, a famous novel (1940), which became a movie in 1968, by Yahya Haqqī (1905-1992), referring to Hišām Qandīl, the prime minister in Mursī's regime. He says: 'indama ta 'ūd ila alMuršid fì al-Muqaț̣am wa-ila Hayrat al-Šạtir wal-Katatn̄̄ wal'iryān wa-qandīl umm Hāšim (p. 78-9). Qandīl umm Hāšim seems odd among the cluster of names mentioned. Țāhir alludes satirically to the movie to arouse the reader's laughter; he downplays the importance of the character of Hišām Qandīl, whom Țāhir disbelieves in his capabilities as a prime minister.

The title 'ašar azamāt wi-astik yihallū al-muwātin al-mașrī mirtāh (Ten crises plus a strip make the Egyptian citizen feel 
Egyptian Political Satire: Parsing the Rhetoric of Parody in Īhāb Ṭāhir's Mursĩ qalb al-asad

Dr. Ahmad M. Ali

مجلة وادي التيل للاراسات والبحوث الإنسانية والاجتماعية والتربوية (مجلة علمية محكمة)

comfortable) refers cynically to an old Egyptian commercial advertisement, promoted in 1983, with slight differences. The advertisement promoted diapers of seven layers plus a strip saba tabaqāt wi-astik, but Țāhir modifies it and transforms the number from saba' into 'ašar, and tabaqāt into azamāt. The ten types of crises Tāhir mentions or reminds the reader of relieve the constraints and obstacles of the Egyptian citizen. This subtitle alludes to a culturally specific advertisement, which addresses kids and children. Logically, burdens and crises do not bring happiness to the Egyptian citizen, but Tāhir goes on his sarcasm.

\subsection{Dramatized crisis scenarios}

Țāhir in each satirical chapter skillfully gives the reader a brief summary of one aspect of the crises Egypt faces from his own point of view. He expresses his views through Egypt, which represents one of the characters playing an important role in most of Tāâh's satirical fantasy movies. For instance, Tāhir demonstrates the reasons behind the rejection of Šafiq as a president of Egypt. He deploys the dialogue between Mașr 'Egypt' and Šafiq skillfully to show all these reasons:

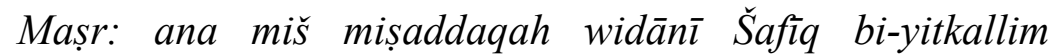
niyābatan 'an ša'b Mașr? mu'żam al-ša'b bi-yikrahak. bilādhum it-saraqit wa-mlākhum d̄à it bi-al-sirqah illī nizāmak saraqha min al-balad hatta inta lamma misikt alwizārah hunt al-tawrah wi-wazza't 'alīhum 'bumbūnì' 'alašān iftakartuhum šuwayyit 'iyāl habbìt tiḍhak 'al̄̄hum wi-faqasūk wa-itaryaqū 'alīk wi-'ala al-bullūvar bi-tā'ak fì al-fisbuk wa-twitar'

Egypt: I cannot believe my ears. Šafiq talks on behalf of the Egyptians? The majority of them hate you; their country has been burgled; and their properties have been taken forcibly from them by your regime. You, in particular, betrayed the Revolution when you got an office in the cabinet; you gave demonstrators candies to fool them, but in vain, they figured 
مجلة وادي النيل للاراسات والبحوث الإنسانية والاجتماعية والتربوية (مجلة علمية محكمة)

(ISSN : 2536 - 9555)

it out and made fun of you and your sweater on Facebook and Twitter. (p. 83)

Egypt, here, as a character in the dialogue, justifies the reasons why the Egyptians hate Šafiq, a representative of the corrupted regimes, who stole their money and took over their properties. She reminds him of his sweet tricks he played on the Egyptians, whom he thought they were young enough to be brainwashed by his candies, but they understood his tricks and made fun of him on the social media, like Facebook and Twitter.

In this regard, Tāhir also justifies the reason behind choosing Mursī and voting for him as opposed to Šafìq. Egypt is employed to act the role of Tāahir and to show his views dramatically, as follows:

Maṣr: al-nās bi-tikrah Šafìq wib-yihibbū Mursī? al-nās 'awza Mursī kurhan fì Šafíq la'annuh min al-fulūl miš hubban fì Mursī .. inta lāzim tifham dah kuwayyis wi-balāš al- gurūr yimlāk wi-tiftikir innak law nağaht wi-fuzt bi-'ař́ Mașr tibqa tistahiqquh .. la'ann dah haykūn gasbin 'an alnās la'ann al-muqāranah inhașarit binkum intum al-itnīn bass.

Egypt: People hate Šafĩq and love Mursī? People want Mursī against their will, as they hate Šafīq, who is one of the old regime; neither do they love Mursī. You should understand that well and not be conceited, thinking that if you win (in the presidential elections) and get the throne of Egypt, you deserve it. If so, this will be out of the people's hands, as comparison is only between you both. (p. 82)

Here, Țāhir shows that Mursī was elected president of Egypt on account of their hate of Šafíq, his opponent in the presidential elections. They were obliged to vote for Mursī, not out of love for him. He reminds Mursī of the fact that his victory in the elections does not mean his worthiness of ruling Egypt, as this will be out of 


\section{Egyptian Political Satire: Parsing the Rhetoric of Parody in Īhāb Ṭāhir's Mursĩ qalb al-asad}

Dr. Ahmad M. Ali

$$
\text { مجلة وادي الثيل للاراسات والبحوث الإنسانية والاجتماعية والتربوية (مجلة علمية محكمة) }
$$

their hand. The competition between the two candidates was undesirable, and the choice of Mursī was 'the better of two evils'.

\subsection{Dramatic \& cinematic recalls}

In a satirical chapter entitled $A b \bar{u}$-Ismā $\bar{l} l$ yuhaddid sāit al-șifr (Abū-Ismā̄îl sets the zero hour), Țāhir professionally opts for a very expressive subtitle through which he builds up a very humorous script, which embodies his critical view on the Islamists and their movement. The subtitle consists of two elements, the doer, i.e., Abū-Ismā $\bar{i} l$, and the action he plans to carry out, which is disclosed to the reader at the end of the chapter, i.e., the siege of the Media Production City. So, the dialogue is of two parties, AbūIsmā' $\overline{1} l$, representing the boss, and awlād $A b \bar{u}-I s m \bar{a} ' \bar{l}$ l, representing his 'henchmen' as their name suggests. TTāhir attempts to show the state of closeness, familiarity, and intimacy between the boss and his guys. When reading the chapter, the reader recalls a cinematic scene in the famous Egyptian movies, such as Samarah, starring Maḥmūd Ismā'îl, who acted the role of al-Ma'allim Sulțān, and rașîf nimrah 5, starring Zakī Rustum, who acted the role of alMa'allim Bayyūmī. Both of them played the role of the drug traffickers. These movies revolve around the gang that is chased by the police to arrest these groups of criminals and drug dealers, who are always depicted as outcasts, forming evil plots all the time. The script as a whole is very dynamic and full of gradual actions to be taken as a result.

The actors of the scene are two major characters, $A b \bar{u}-I s m \bar{a} \bar{i} l$ and awläd $A b \bar{u}-I s m \bar{a} \hat{\imath} l$. It is successfully initiated by posing a question of Abū-Ismā 'îl about the danger that may face their boss, and if their boss is faced with dangers, their Ğama 'ah 'the Group' is also exposed to danger, and consequently Islam is in danger. This kind of escalation arouses the anxiety of his men, who reply immediately al-islām lahu rabbun yihmīh 'Islam has a Lord to protect it'. In response to their reply, Abū-Ismā'īl asks another question to get an oriented answer; he questions them, as follows: 
(ISSN : 2536 - 9555)

wil-Muršid wil-hāal Hayrat wil-rayyis Mursī wa-maktab al-iršād min yihmīhum? 'Who will protect al-Muršid, uncle Hayrat, the president Mursī, and the MB's headquarters?' Here, the epithets are to be on the lips of awlād Abü-Ismã $\bar{\imath} l$ intentionally by Țāhir, who chooses very suitable epithets for each character according to his view, exemplified in al-Muršid, al-hăl and al-rayyis. Without hesitation, his men are voluntarily willing to take the action, ihna nihmīhum yā kibirnā 'we are up to it, boss'. Their protection tactics are the use of bi-al-šüm wil-hiğārah wi-kasr al-ruhām wil-izāz 'cudgels, stones, and broken pieces of marble and glass' and in case of emergency they may resort to using wa-in lazama al-amr bi-al-harțūs 'cartridges, when necessary'. But their suggestion is opposed by Abū-Ismā̄îl, who directs them to ihna niḥassir almadinah ğuwwah wi-barrah 'we will besiege the (Media Production) City, from inside and outside' and win-dibb al-ru' $b$ fi nufüs al-i 'lämiyyin 'we terrify the media men (there)'.

The language used in the dialogue is colloquial, representing the real identity of the participants, according to Țāhir's view. He adopts certain epithets of address between the boss, Abū-Ismā 'îl,

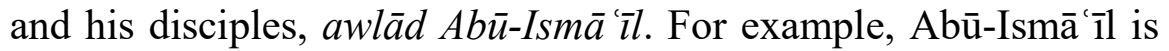
addressed $y \bar{a}$ kibirna $\bar{a}$ and $y \bar{a}$ kibi $\bar{r}$ by his disciples, as he, for them, represents their boss, who addresses them as $y \bar{a} a w l \bar{a} d$, as they, for him, represent his thugs.

Finally, Tāhir ends his chapter similarly as deals of dealers do; the words of agreement and approval are uttered by awläd $A b \bar{u}$ Ismā $\bar{l} l$ as in istabina, which is derived from the Italian origin sta bene, meaning 'agreed/done' (Badawi and Hinds, 1986, p. 19). The meeting is declared to be finished on the tongue of the boss, AbūIsmā' 1 l, as in inșarifū 'go ahead', a sign of leaving, wishing them safe outgoing, bidding them farewell, as in fi ri 'ayyat Allāh ya awlād ' 'be in Allāh's providence, my sons', calling them his sons. 


\section{Egyptian Political Satire: Parsing the Rhetoric of Parody in Īhāb Ṭāhir's Mursĩ qalb al-asad}

Dr. Ahmad M. Ali

$$
\text { مجلة وادي النيل للاراسات والبحوث الإنسانية والاجتماعية والتربوية (مجلة علمية محكمة) }
$$

\subsection{Script opposition (Attardo and Raskin 1991)}

'Script opposition', one of the six Knowledge Resources (KRs) proposed by Attardo and Raskin (1991), simply means that "the text of [the satirical discourse] is always fully or in part compatible with two distinct scripts ... [which] are opposed to each other in a special way" (p. 308). The text implies, as Simpson (2003) argues, "the transition between positive and negative polarities" and "the alteration between normal and abnormal scripts" (p. 79). In this regard, Tāhir seems to be neutral in his description of the events and the persona as well, but this is not usual. For example, he initiates his talk about the MB, as the second candidate in the 2012 presidential elections. He numerates the obstacles and challenges they confronted. They were fought, imprisoned, detained, and severely tortured on the hands of the previous regimes, as they, as a party, were vehemently oppressed.

Fa-al-munāfis al-țānī ata min fașil kāna ma zùlan 'an muğrayāt al-aḥdāt fì Mașr mundِu zaman ba ìd .. fașīlan kāna mudțahadan .. nakkalat bihi kull al-anzimah alsābiqah wa-hāarabathu wa-sağanathu wa-i taqalathu waad̄āqathu al-marār

The second rival came from a party isolated from the events in Egypt a long time ago; a party that was oppressed by the past regimes, attacked, prisoned, arrested and tortured severely to death. (p. 13)

Țāhir's "violation of a moral principle ... is regarded as benign, nonthreatening, and consequently acceptable" (McGraw \& Warren, 2010, p. 1142, as cited in Oring, 2016, p. 57). Tāhir here declares directly that Mursī is not a personal enemy to him, but he seems to violate his declaration benignly. He indirectly criticizes Mursī through promising his readers that he will avoid talking about Mursī's blunders, on which he increasingly and intentionally elaborates. For example, he says: 
(ISSN : 2536 - 9555)

Ana lan atakallam 'an hițābāt Mursī aw țarīqat adā'uh aw išarātuh aw așābi uh wa-lan atakallam 'an al-ruğ̄u' fí qararātuh aw qararātuh al-hă'ibah allatī lam yakun ayyan minha șä̀iban .. ana lan atakallam 'an balbalatih aw tahtahtuh aw lugiatuh al-a ğnabiyyah al-rakīkah aw uslübuh (al-fasahāōì) (al-maștabāwì) .. lan atakallam 'an sa'tuh aw hātifuhu al-mậmūl .. lan atakallam 'an alfāzuh wata bìrātuh wa-tašbihātuh ... wa-lan atatarraq ila ğumal "alhārah al-maznūqah" aw "al-așābi 'allatī tal 'ab fì Mașr" I will not talk about Mursī's speeches or the way he behaves, or his gestures, or his fingers. I will not talk about his vows' breach or his bad decisions, of which none was right. I will not talk about his irrationality, his stuttering, or his bad foreign language, or his 'barbaric' behavior. I will not talk about his watch or his cell phone. I will not talk about his lexical choice of words, expressions, and examples. I will not talk about his phrases, including 'a surrounded dead end' and 'fingers that play in Egypt'. ( $p$. 18)

Suddenly, without any reason or justification, he adopts direct and open attack; his 'intense personal involvement' in the comments he gives is vividly shown through the pictorial drawing of the MB. He makes the readers feel sympathy with them, and all of a sudden they find out that the MBs are only to blame; all various kinds of torture and segregation are the possible outcome of their intellectual extremism and radicalism. Țāhir uses the narrative shift recurrently to surprise the reader. Instead of sympathizing with the object of satire through seemingly incongruous descriptive words, he turns to satire. Here, the reader expects something positive and supportive will be said, but s/he receives the opposite, as in:

Wa-ad̄āqathu al-marār li-ğunūh fikrih wa-tațarrufuh .. fașilan kāna kull hilmihī an yașil ila suddat al-ḥkm ... waata al-șandūq bi-murrǎ̌šah al-ihwwān (Mahammad Mursī ra 'ìsan wi-ka'inn al-nās istağārit bi-al-ramḍ̄a' min al-nār) 


\section{Egyptian Political Satire: Parsing the Rhetoric of Parody in Īhāb Ṭāhir's Mursĩ qalb al-asad}

Dr. Ahmad M. Ali

مجلة وادي التيل للاراسات والبحوث الإنسانية والاجتماعية والتربوية (مجلة علمية محكمة)

(This group was) tortured severely due to their intellectual extremism and radicalism. It was a group whose dream was to reach the throne of power ... The MB's nominee, Mahammad Mursī, came through the ballot box. Thus, people (the Egyptians, who voted for him) are like those who jumped out of the frying pan into the fire. (pp. 13-4)

In doing so, he pretends to be biased and detached from the twisted facts, but he, through his satirical work, attempts to counter the struggle and the 'wrongdoings' of the MB. Thus, he establishes an ostensibly objective validity so that the readers can readily accept and accordingly react.

\subsection{Intellectually engaged readers}

Țāhir satirically depicts the pious character of al-Muršid and alŠațir through the call of al-Muršid to prayer, as in yalla biña niṣallī wi-niddī Rabbina a haqquh 'let's go praying to God, performing our obligation' (p. 60). Sarcastically, Țāhir ends his chapter with the religious aspect of al-Muršid and al-Šățir after their evil scheme and wrongdoings. This is of course arouses the reader's astonishment and shock as well, due to the contradiction in their personalities, as they robbed Egypt and give God a prayer as His share of the loot. That is why Țāhir closes the chapter, leaving a space to the reader to have his comments. Țāhir ends his chapter, commenting satirically on their behavior, wa-yadhaba lil-șalāh ... 'then, they go to pray'. The space left here indicates the unsaid comment by the reader, such as ba'd da kulluh rayhin yișallu 'after all that, they go to pray', or bilā rağ 'ah 'go to hell', or šüf izzay 'How dare they?'

\subsection{Dialogue-fit character}

Among Țāhir's salient techniques is using language that matches the speaker. He is good at using functional dialogues uttered by appropriate participants, who represent various intellectual, political, and religious categories. To explain, Tāanir includes 
(ISSN : 2536 - 9555)

various characters in his work from different backgrounds. AlBarad' $\overline{1}$ represents the liberal trend; Hamdīn represents the leftist trend; Abū-Ismā îll represents the Islamist trend; Maẓhar Šāhīn represents al-Azhar; 'Amr Hamzāwī represents the moderate liberal trend, to name just a few. For example, Šāhīn, who represents al-Azhar, uses words and phrases of religious specificity; he says: dah ibtila ' bass ihna la azzim nistahmil 'this is a tribulation we should endure'. The word ibtila ', meaning 'tribulation or ordeal', requires patience, which reflects the character of a religious person.

As for Abū-Ismā'îl, Ṭāhir employs his character to send a certain message to the reader; he believes that the MB attempted to transform Egypt into a religious state, governed by Islamic rulings. For example, women should wear niqāb 'full facial covering', as a means of preventing the spread of sins and wrongdoings; cigarettes, hookah and liquor will be banned; women's work will be banned; men will wear Islamic garments, growing a beard and clipping their moustaches. All these views are expressed by AbūIsmā ‘̄il's dialogue with Ḥamdīn, as follows:

Wa-an takūn Maṣr dīniyyah taḥkumhā al-šarīah alislāmiyyah tantaqib fiha al-nis $\bar{a}^{\prime}$ man 'an lil-bala ${ }^{\prime}$ wadar'an al-faḩšă' [sic] wa-tumna ' fìhā al-sağāyir wa-bì' alhumūr wa-tuġlaq fîhā al-maqūhī wil-mawāhnìr wa-yu'mal fihā bi-hadd al-hirābah wi-'adam 'amal al-mar'ah wi'adam tawāğudhā fi al-šāri' ba'd al-tāsi 'ah masāan an wi'ala al-rig̀āl libs al-gìilbāb al-šarì' wa-ițlāq al-liḥa wi-qașs al-šawārib

Egypt is to be (a) religious (nation), ruled in terms of the Islamic jurisdiction, under which women wear niqā b 'full facial covering' to avoid the spread of vice; cigarettes and liquor are banned; cafes and brothels are to be closed; the prescribed punishment for highway robbery is to come into force; women's work is forbidden and they should not walk 


\section{Egyptian Political Satire: Parsing the Rhetoric of Parody in Īhāb Ṭāhir's Mursī qalb al-asad}

Dr. Ahmad M. Ali

مجلة وادي النيل لللاراسات والبحوث الإنسانية والاجتماعية والتريوية (مجلة علمية محكمة)

in streets after $9 \mathrm{pm}$; men are to wear Islamic gown, to wear beards, and to cut their moustaches. (pp. 89-90)

\section{IV- The conclusion}

The purpose of this paper was to analyze the literary work of İhāb Ṭāhir, entitled Mursī qalb al-asad 'Mursī, the lion's heart' (2013). It is a political satire employed by Țāhir to voice his own opinions, using irony, sarcasm and allusions to criticize social, economic or political issues, and to indicate mockery of salient figures, particularly Mursī, the former president of Egypt, and his party, the Muslim Brotherhood (MB). This paper attempted to show how Țāhir, through his satirical and political parody, found an emotional vent, for the ordinary people of Egypt, through which they could get rid, even if temporarily, of their recurrent encumbrances and burdens of life, enabling them to restore their stolen democracy, freedom of expression, and liberty. To achieve such a purpose, a Pentadic Satirical Script Theory of Verbal Humor (PSSTVH) was proposed, depending greatly on Paul Simpson's (2003) theoretical model of satirical discourse analysis. The theory suggested that five constituents, as expounded above, namely 'the satirist', 'the satiree', 'the satirized', 'the medium', and, finally, 'the tools', form the basis on which any satirical script or activity depends. It investigated Țāhir's style of writing, through which his satirical activity is delivered, and his satirical techniques, adopted to convey his message efficiently.

Regardless of judging Țāhir's own views, biased by personal considerations and communal justifications, the results of the analysis focused specifically on his artistry in political satire and his techniques of depicting visually the object of satire. TTāhir has efficiently created an 'objective validity' his audience can never overlook despite his 'intense personal involvement' and overt participation in the satirical discourse, commenting sarcastically on the events, or criticizing ostensibly both the individual and partisan politics. In other words, Țāhir, as a talented satirist, has succeeded 
(ISSN : 2536 - 9555)

in making his satiric voice heard, focusing on "the pre-existence or creation of shared comprehension and evaluation" (Maslo, 2019, p. 232) between him and his audience. His firm belief in the effectiveness of laughter, which is certainly 'an important outcome' in the satirical discourse, depends on the tools or techniques of satire used entirely. These satirical techniques or strategies were examined through the proposed PSSTVH, which helps increase the appreciation of the satirical discourse by his audience. It highlighted Țāhir's benign violation of his audience's expectations, "putting the target into imaginary, exaggerated, impossible, improbably or merely far-fetched scenario which, as a whole, contributes to the humor of satirical discourse" (Maslo, 2019, p. 239).

\section{Aknowledgments}

I am extremely grateful to the Egyptian Mission Sector, Ministry of Higher Education, Egypt, which offered me a fully funded 6month postdoctoral scholarship to the University of Emory, GA, USA. I am also grateful to Devin Stewart, Professor of Arabic and Islamic Studies and MESAS Chair, Emory University, GA, USA, whose inspiring suggestions and comments on the preliminary and final versions of this paper contributed to its completion. I appreciate his time and great efforts. Despite his academic and family commitments, he spared no effort to give priotiy to my paper.

\section{Endnote}

${ }^{1}$ As for the author's biography and the history of his satirical world, I tried many times to contact the author himself electronically via his email written down at the end of his work under study or to contact the publishing house via phone, but in vain. 


\section{Egyptian Political Satire: Parsing the Rhetoric of Parody in Īhāb Ṭāhir's Mursī qalb al-asad}

Dr. Ahmad M. Ali

مجلة وادي النيل للاراسات والبحوث الإنسانية والاجتماعية والتربوية (مجلة علمية محكمة)

${ }^{2}$ According to the list of Tāhir's works, various editions of his past five books were published in different periods of the year 2010; these five works are, as follows: $r a ' \bar{l} s$ gumhüriyyit nafsì 'the president of the republic of myself' ( $4^{\text {th }}$ ed.) (July 2010), tuzz fikum 'I don't care' $\left(3^{\text {rd }}\right.$ ed.) (Jan. 2010), hamra 'red' (4 ${ }^{\text {th }}$ ed.) (Sep. 2010), Maṣr 'ala mūğah kumidī 'Egypt's on Mūğah Comedy' (1 ${ }^{\text {st }}$ ed.) (Jan. 2010), and ummak ismaha hanafì ‘your mom's name is Hanafī' ( $2^{\text {nd }}$ ed.) (Jan. 2010).

${ }^{3}$ All the translations included in this paper are mine, unless otherwise indicated. In most cases, for the purpose of the study, they are as literal as they could be.

${ }^{4}$ The exact wording attributed to Ibn Hazm is man tasaddara li-hidmat al- 'āmmah fa-lābudda ann yataṣaddaq bi-ba'ḍin min 'irḍih 'ala al-nās li-'annahu lā-maḥālah maštūm hatta wa-in wāṣala al-layl bi-al-nahār. Though I did my best as much as I could to verify his quote and to find a true reference to it, but no authoritative source I have found.

5 Some authors' Arabic names in this paper are written as they appear in the original sources.

${ }^{6}$ The relevant previous studies are chronologically arranged, except for the works of Håland and Ibrahim \& Eltantawy, which are alphabetically arranged.

7 The Arabic words are omitted from the original translation in this paper.

${ }^{8}$ The original reads: malā yudrak kulluh lā yutrak ğulluh ('Umar, 2008, p.386).

${ }^{9}$ Qandīl umm Hāšim refers to the lantern of the Mosque of Sayyida Zaynab. 
مجلة وادي النيل للاراسات والبحوث الإنسانية والاجتماعية والتربوية (مجلة علمية محكمة)

(ISSN : 2536 - 9555)

\section{References}

Alansari, Wahab. (2009). An anthology of Arabic poetry. Seattle: Academy of Languages.

Al-'Isīlī, Aḥmad. (2011). Al-kitāb al-tānī (The second book). Cairo: Dar al-Šurūq.

Alkodimi, A. Khaled and Omar, Noritah. (2010). Satire in Sonallah Ibrahim's The Committee: An allegory to ridicule capitalism. GEMA Online Journal ${ }^{\mathrm{TM}}$ Journal of Language Studies, 10(3), 53-65.

Anagondahalli, Deepa and Khamis, Sahar. (2014). Mubarak framed! Humor and political activism before and during the Egyptian revolution. Arab Media and Society (19), 1-16.

Anderson, J., \& Kincaid, A. D. (2013). Media subservience and satirical subversiveness: The Daily Show, The Colbert Report, the propaganda model and the paradox of parody. Critical Studies in Media Communication, 30(3), 171-188.

Attardo, S. Raskin, V. (1991). Script theory revis(it)ed: joke similarity and joke representation model, Humor 4/3-4, 293-347.

Attardo, S. (1997). The semantic foundations of cognitive theories of humor, Humor 10(4), 395-420.

Attardo, S. (2001). Humorous texts: a semantic and pragmatic analysis, Mouton de Gruyter, Berlin.

Austin, John L. (1962/1975). How to do things with words. ( $2^{\text {nd }}$ ed.). Oxford: Oxford UniversityPress.

Badawi, al-Sa'īd. (1973). Mustawayāt al- 'arabiyyah al-mu 'ạsirah fi Mașr (levels of contemporary Egyptian Arabic). Cairo: Dar al-Ma'ārif.

Badawi, El-Said and Hinds, Martin. (1986). A dictionary of Egyptian Arabic: Arabic-English. Beirut: Librairie du Liban.

Baer, Gabriel. (2016). Population and society in the Arab East. (Hanna Szoke, Trans.). New York: Routledge, 1964.

Bahğat, Aḥmad. (2009). mudakkirāt zawğ (memoirs of a husband). Cairo: Dar al-Šurūq. 
Egyptian Political Satire: Parsing the Rhetoric of Parody in Īhāb Ṭāhir's Mursĩ qalb al-asad

Dr. Ahmad M. Ali

مجلة وادي النيل للاراسات والبحوث الإنسانية والاجتماعية والتربوية (مجلة علمية محكمة)

Barthes, Roland. (1977). Rhetoric of the image. In his book Imagemusic-text, trans. S. Heath, USA: Library of Congress Cataloging in Publication Data, pp. 32-51.

Cottle, S. (2011). Media and the Arab uprisings of 2011: Research notes. Journalism, 12(5), 647-659.

El Amrani, I. (2011). Three decades of a joke that just won't die: Egyptian humor goes where its politics cannot. Foreign Policy. Retrieved from http://foreignpolicy.com/2011/01/03/three-decades-of-ajoke-that-just-wont-die-2/

Elliot. C, Robert. (1960). The power of satire: Magical, ritual, art. New Jersey: Princeton University Press.

Ezzat, Ali. (1973). Aspects of language study. Beirut Arab University.

Fahmy, Z. (2011). Ordinary Egyptians: Creating the modern nation through popular culture. Stanford, CA: Stanford University Press.

Fauconnier, G. (1994). Mental spaces: Aspects of meaning construction, Cambridge University Press, Cambridge.

Fauconnier, G., Turner, M. (2002). The way we think, Basic Books, New York.

Fletcher, M. D. (1987). Contemporary political satire: Narrative strategies in the post-modern context. New York: University of Queensland.

Gray, J., Jones, J. P., \& Thompson, E. (2009). Satire TV: Politics and comedy in the post-network era. New York, NY: New York University Press.

Håland, Eva Marie. (2017). Adab sākhir (satirical literature) and the use of Egyptian vernacular. Jacob Høigilt and Gunvor Mejdell (eds.) The politics of written language in the Arab world. Brill.

Hasan, Hesham. (2011). Political satire in Egypt during the last decade: A linguistic perspective. Cairo: fikr wa Pibdāe.

Highet, G. (2015). Anatomy of satire. Princeton University Press. 
Hmielowski, J. D., Holbert, R. L., \& Lee, J. (2011). Predicting the consumption of political TV satire: Affinity for political humor, The Daily Show and The Colbert Report. Communication Monographs, 78(1), 96-114.

Holbert, R. L. (2013). Breaking boundaries| Developing a normative approach to political satire: An empirical perspective. International Journal of Communication, 7, 305-323.

Holbert, R. L., Tchernev, J. M., Walther, W. O., Esralew, S. E., \& Benski, K. (2013). Young voter perceptions of political satire as persuasion: A focus on perceived influence, persuasive intent, and message strength. Journal of Broadcasting \& Electronic Media, 57(2), 170-186.

Ibrahim, Amal \& Eltantawy, Nahed. (2017). Egypt's Jon Stewart: Humorous political satire and serious culture jamming. International Journal of Communication, 11, 2806-2824.

Jacquemond, Richard. 2016. Satiric literature and other popular literary genres in Egypt today. Journal of Arabic and Islamic Studies 16, 349-367.

Jenny, Laurent. (1982). The strategy of form. French literary theory today: A reader, ed. Tzvetan Todorov, Trans. R. Carter. Cambridge: Cambridge University Press, 34-63.

Johnson, Edgar (1945). A treasury of satire. New York: Simon and Schuster.

Khamis, S. (2008). Modern Egyptian media: Transformations, paradoxes, debates and comparative perspectives. Journal of Arab and Muslim Media Research 1(3), 259-277.

Klinkowtiz, Jerome. (1990). Mother night, cat's cradle, and the crimes of our time. Critical Essays on Kurt Vonnegut. Ed. Robert Merrill. Boston: G. K. Hall, 82-93.

Lane, Edward William (1908). The manners and customs of the modern Egyptians. London: Everyman's Library.

LeBoeuf, Megan. (2007). The power of ridicule: An analysis of satire. Senior Honors Projects, 1-63.

Maslo, Adi. (2019). Parsing satirical humor: A model of cognitivelinguistic satire analysis. Knjizevni Jezik, 231-253. 
Egyptian Political Satire: Parsing the Rhetoric of Parody in Īhāb Ṭāhir's Mursĩ qalb al-asad

Dr. Ahmad M. Ali

مجلة وادي النيل للاراسات والبحوث الإنسانية والاجتماعية والتربوية (مجلة علمية محكمة)

McGraw, A. Peter, and Warren, Caleb. (2010). Benign violation: Making immoral behavior funny. Psychological Science, 21(8), 1141-49. http://dx.doi.org/10.1177/0956797610376073.

Mejdell, Gunvor. (2006). Code-switching. Encyclopedia of Arabic Language and Linguistics, Vol. 1, ed. by K. Versteegh. Leiden-Boston: Brill, 414-421.

Nash, Walter. (1985). The language of humor. London: Longman.

Oring, Eliott. (2016). Joking asides: The theory, analysis, and aesthetics of humor. University Press of Colorado.

Peterson, L. Russell. (2000). Strange bedfellows: How late-night comedy turns democracy into a joke. New Jersey: Rutgers University Press.

Pfaff, K. \& Gibbs, R. (1997). Authorial intentions in understanding satirical texts. Poetics, 25, 45-70.

Rāgiib, Nabīl. (2000). Al-adab al-sāhnir. Cairo: Al-Hay'ah alMișriyyah al-' 'Āmmah lil-kitāb.

Radwan, Noha. (2020). Post-coup recuperation in al-Manawahly's songs. International Journal of Cultural Studies, 23(2), 193 $-207$.

Ritchie, G. (2004). The linguistic analysis of jokes. London: Routledge.

Rosen, R. M. (2012). Efficacy and meaning in ancient and modern political satire: Aristophanes, Lenny Bruce, and Jon Stewart. Social Research, 79(1), 1-32.

Rosenbaum, Gabriel M. (2000). Fuṣhammiyya: Alternating style in Egyptian prose. Journal of Arabic Linguistics, (38), 68-87.

Rosenbaum, Gabriel M. (2012). Mixed Arabic and stylistic choices in contemporary Egyptian writing. Au-Delà De L' arabe Standard: Moyen Arabe Et Arabe Mixte Dans Les Sources Médiévales, Modernes Et Contemporaines, Vol. 28, Quaderni Di Semitistica, edited by L. Bettini and P. La Spisa. Firenze: Dipartimento di scienze dell'antichità, 
مجلة وادي النيل للاراسات والبحوث الإنسانية والاجتماعية والتربوية (مجلة علمية محكمة)

(ISSN : 2536 - 9555)

Medioevo e Rinascimento e linguistica, Università di Firenze.

Scott, Clive. (1999). The spoken image: photography and language. Reaktion Books Ltd.

Shultz, T. R. (1976). A cognitive-developmental analysis of humour. Chapman, A. J., Foot, H. C. (eds) Humour and Laughter: Theory, research and applications (1st ed.). London: Transaction Publishers, 11-36.

Simpson, P. (2003). On the discourse of satire: Towards a stylistic model of satirical humor. Amsterdam \& Philadelphia: John Benjamins Publishing Company.

Sinatora, Francesco L. (2016). Hybridity and superdiversity on Syrian dissidents' Facebook pages: An online ethnography of language, identity and authenticity. Unpublished $\mathrm{PhD}$ Dissertation. Georgetown University, USA.

Suls, Jerry M. (1972). A two-stage model for the appreciation of jokes and cartoons: An information-processing analysis. The psychology of humor: Theoretical perspectives and empirical issues, 1, 81-100.

Suls, Jerry M. (1977). Cognitive and disparagement theories of humour: A theoretical and empirical synthesis. Chapman and Foot, 41-45.

Test A. George. (1991). Satire: Spirit and art. Tampa: University of South Florida Press.

Thomas, R. F. (1986). Vergil's Georgics and the art of reference. Harvard Studies in Classical Philology, 90, 171-98.

'Umar, Ahmad Muhtar. (2008). Mu'ğam al-Lugiah al- 'Arabiyyah al-Mu'āșirah. Cairo: 'Ālam al-Kutub.

Valassopoulos, Anastasia and Mostafa, Dalia Said. (2014). Popular protest music and the 2011 Egyptian Revolution. Popular Music and Society 37(5), 639-59.

Watson, Janet C. E. (2002). The phonology and morphology of Arabic. New York:

Oxford University Press. 
Egyptian Political Satire: Parsing the Rhetoric of Parody in Īhāb Ṭāhir's

مجلة وادي التيل للاراسات والبحوث الإنسانية والاجتماعية والتربوية (مجلة علمية محكمة)

\section{Online Sources}

Double entendre. (n.d.). Thefreedictionary.com. Retrieved from https://www.thefreedictionary.com/double+entendre

Fantasy. (n.d.). Thefreedictionary.com. Retrieved from https://www.thefreedictionary.com/fantasy

Axiom. (n.d.). Thefreedictionary.com. Retrieved from https://www.thefreedictionary.com/axiom

Stumble. (n.d.). Thefreedictionary.com. Retrieved from https://www.thefreedictionary.com/stumble

'atara. (n.d.). Almaany.com. Retrieved from https://www.almaany.com/ar/dict/arar/\%D8\%B9\%D8\%AB\%D8\%B1/

\section{Appendix Arabic Transcription System}

\section{A- Phonetic Alphabet}

\begin{tabular}{|c|c|c|}
\hline & $\varepsilon$ & Voiceless glottal stop \\
\hline & ث & Interdental voiceless fricative \\
\hline$\check{\mathbf{g}}$ & ج & Voiced palatal fricative \\
\hline & $\tau$ & Voiceless pharyngeal fricative \\
\hline & $\dot{\tau}$ & Voiceless uvular fricative \\
\hline$\underline{\underline{\mathbf{d}}}$ & j & Interdental voiced fricative \\
\hline$\check{\mathbf{s}}$ & ش & Voiceless palatal fricative \\
\hline ș & ص & Voiceless pharyngealized fricative \\
\hline de & ض ض & Voiced pharyngealized plosive \\
\hline t & b & Voiceless pharyngealized plosive \\
\hline & ظ & Voiced pharyngealized fricative \\
\hline & $\varepsilon$ & Voiced pharyngeal fricative \\
\hline$\dot{\mathbf{g}}$ & $\dot{\varepsilon}$ & Voiced uvular fricative \\
\hline $\mathbf{q}$ & ق & Voiceless uvular plosive \\
\hline $\mathbf{y}$ & ي & Voiced palatal semi-vowel \\
\hline
\end{tabular}


(ISSN : 2536 - 9555)

B- Vowels:

\begin{tabular}{|c|c|c|}
\hline \multicolumn{2}{|c|}{ Vowels } & Examples \\
\hline Short & $\mathrm{a}$ & bab 'door' \\
& $\mathrm{i}$ & min 'from' \\
& $\mathrm{u}$ & $f u l$ 'jasmine' \\
\hline Long & $\overline{\mathrm{a}}$ & waf $\overline{\mathrm{a}}$ ' 'loyalty' \\
& $\overline{\mathrm{i}}$ & $f \bar{l}$ 'in' \\
& $\overline{\mathrm{u}}$ & mul $\bar{u} k$ 'kings' \\
\hline
\end{tabular}

- ' (hamza) is not used in the initial position of Arabic words, as in Amīr not 'Amīr.

- Doubled consonants are used to indicate gemination in Arabic.

- The consonantal sounds /g/ and /j/ correspond to the Cairene Arabic phonemes gìm, as in gamal (camel) and jīm, as in bijāma (pyjamas), respectively. 